\section{$3 \cdot 3$ 材料の強さ}

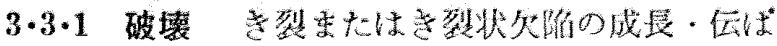

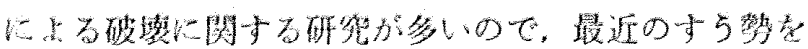

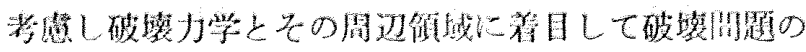

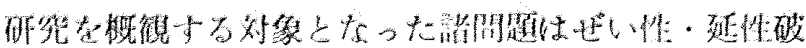

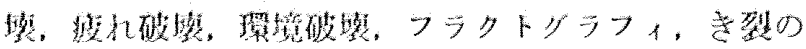

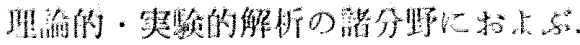

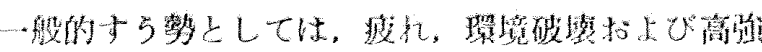
度の铜、 $\mathrm{Al}, \mathrm{Mg}, \mathrm{Ti}$ 合金，ダラス、コンクリート

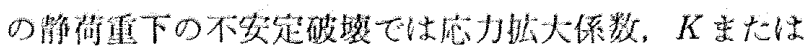
それに若千の修正を加えたものに上る解析が多く，顿

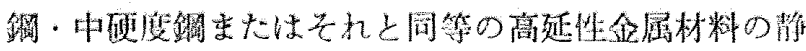

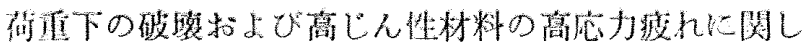

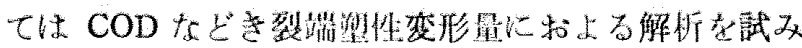

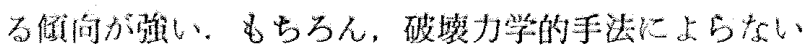
整理や理渝香数多いが,ここでは省略する。

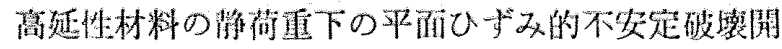

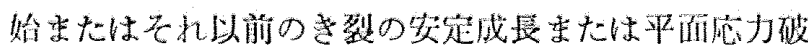

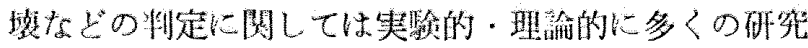

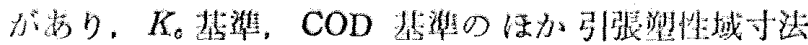

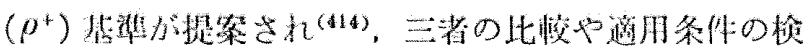

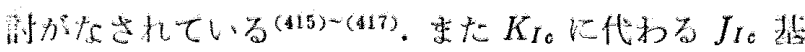

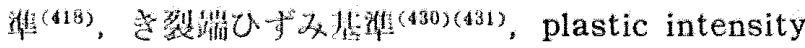
factor 基泪(419)(428)などの提案が㧍り，新しい理湓と

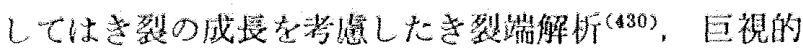

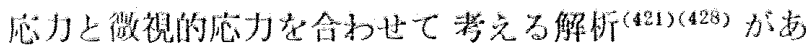

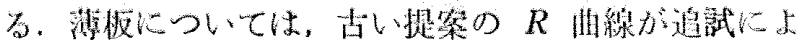

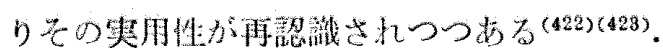

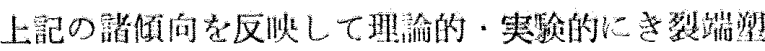
性城の解析が数多く進められている(416)(416)(420)(424) (427)(429) (432)(453).

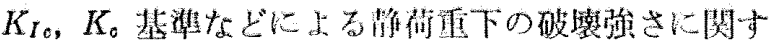

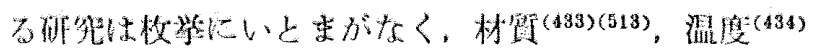

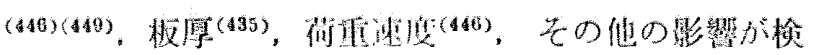

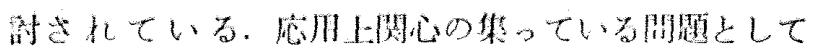

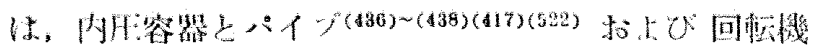

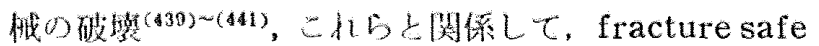

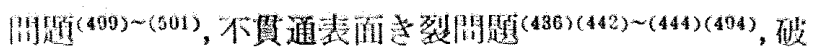
壊じん性上衝撃值の関係(445)(447)(448)(513)，実験方法の 检钨·改艮(425)(450) (453)(455) (457)(459)(457)(468)(516)，久陷

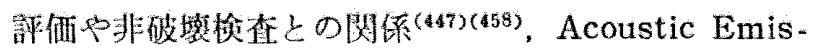
$\operatorname{sion}^{(460)(519)}$ などがある。

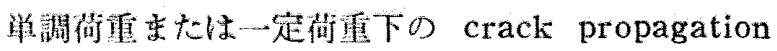
について多多くの理諭的 ${ }^{(461)(463)(466)(497)}$. 実験的 (450) (462) (485)(469) (471) 研管が行なわれていて, 伝ば速度,
停止特挫, dynamic stress intensity factor, 実駼 方法などが議销されている。

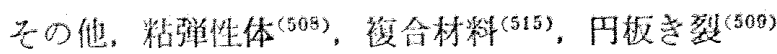

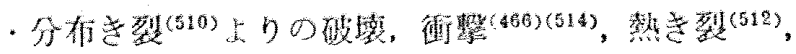

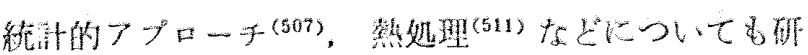
笔虫九ている。

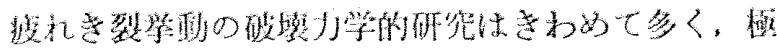

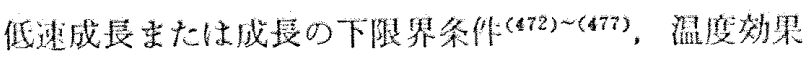

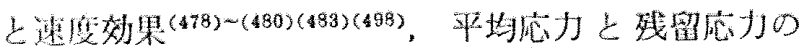

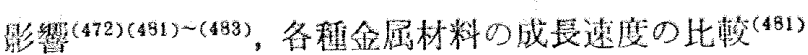

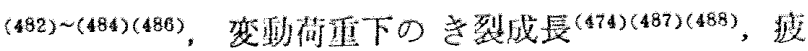
れ裂端の塑性域(489) (491)，成長速度の理諭(492)，粘

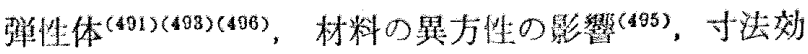

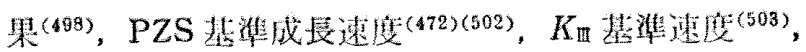

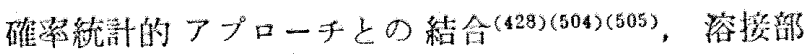
(508) その他多くの砸㚾がある. 理䃋(517) と諎特侳 ${ }^{(518)}$ をまとめたものもある。フラクトグラフィと関係すけ た研究是多い。

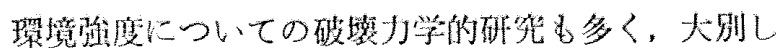
て，(a) 材料の各程環境也゙い化の破塤力学的实駼力 法长上る要因分析，(b) 高虽度の鉬，Al 合金， Ti

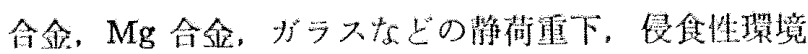
(aggressive environment) 中での筆一裂の安定成

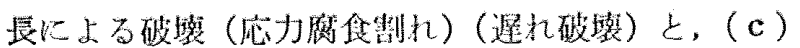

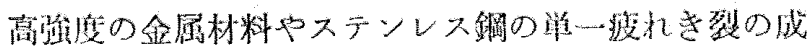

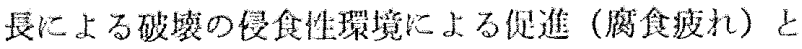
が五刘缘であるが，それ以外の一般の摆境溞度に対す

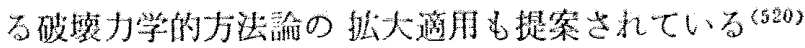

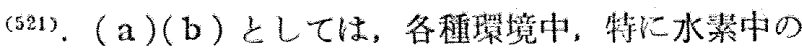

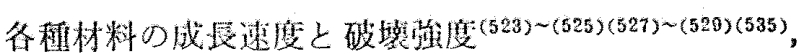

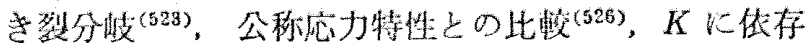

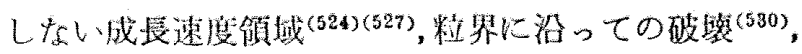

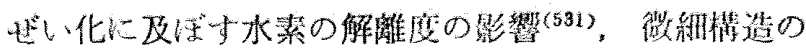

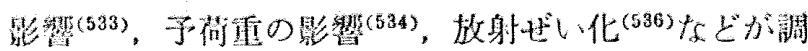

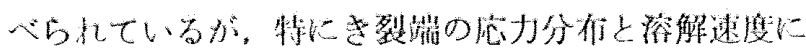

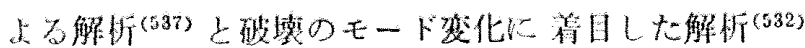

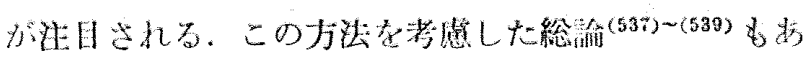

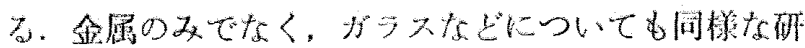
究がされている(540)(541)，(c) 飞ついては，水素，全

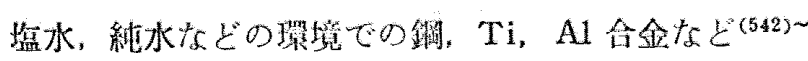

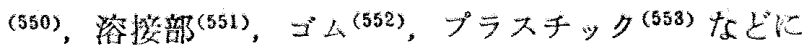
ついての研觉があるほか，真空中での striationの

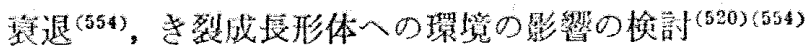

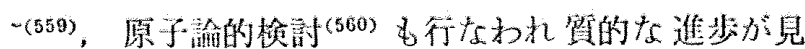
られる、特に注目ず代点としては，腐食疲れき裂の K传存性の内容が比較的明確になってきたことで, 


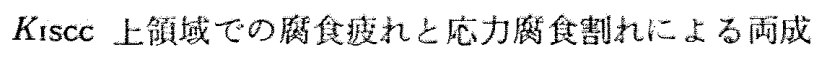
長速度の線形加算法則方一般的に 上下領城の特性分離が試灭られるよ5になり(525)(542)

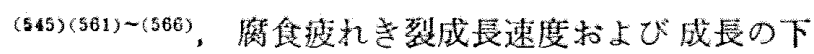
限界条件につにて各種の运則が競合した (562) (564)(566) 画期的な年であると思われる. 以上の上 らな線形破壊力学の適用の活発化に対応して, 裂の 弾性解析と，計算方法の開発改庭当含めて多くの埸合

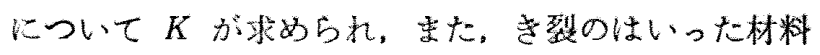
の変形毛解析されている ${ }^{(567) \sim(594)}$. [北川 莫夫]

$3 \cdot 3 \cdot 2$ 疲れ退九に関係寸る研究は依然盛儿で あり，文腩数も年々增加している ${ }^{(505)}$. とくに 8 月

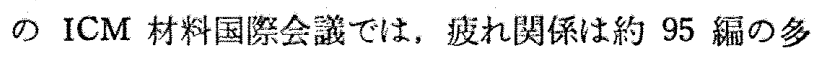
きに塳し，引続さ行なわれた高温強度やX線材料强度 のセミナーの中でも痩れに関するものが多い.

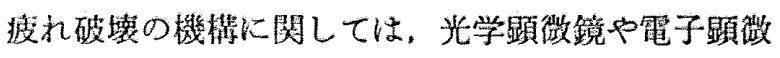
鏡，期束X線などによる微視的観察とき裂成長速度の 実測が备揫の材料について行なわれ，これらの結果に 破填力学の理論を適用して惨討されている場合が多

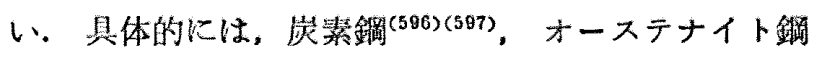

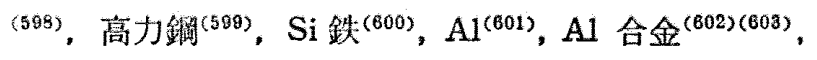

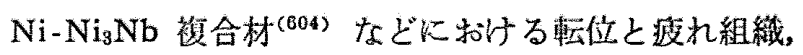
すべり,さ裂発生伝ばの钼察や，鋼(605) (807), $\mathrm{Al}^{(608)}$, $\mathrm{Al}$ 合金 ${ }^{(600)}, \mathrm{Ni}$ 基合金 ${ }^{\left({ }^{(610)}\right.}$ の疲れ破面の観察結果が あり,フラクトグラフィに関する総説的記述 ${ }^{(011)}$ むる る.さらに細束X線を併用して，炭紫鐦 ${ }^{(612) ， オ ー ス ~}$

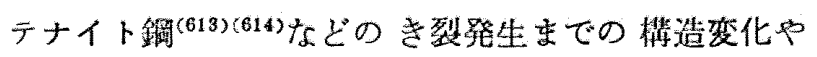
き裂近傍の変形機權(615)(616)が調べられた。

き裂成長速度の俸测にもとづく研究結果としては， $\mathrm{Cu}^{(617)(619)}, \mathrm{Cu}-\mathrm{Al}$ 合金 ${ }^{(617) \sim(619)}$, 純 $\mathrm{Al}^{(620) \sim(622)}$, 萿

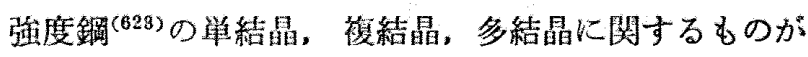
あり，過去のこうした夷験繥果について応力执大係 数による整琹(624)(625) むなされている. 理喻面では非 弾性体中の气裂進展理䛺(626) や多結晶材料の波九学動 のシミュレーション(627)などが注目され，継続確䇣過 程としてのき裂伝ぱの考察 ${ }^{(029)}$ あある. その他, 実験 結果と理諭についての総説的記述 ${ }^{(629) \sim(632)}$ むなされて いる.こうした疲れさ裂発生の核となる欠陷や介在物 に着目した研究として，銅の人工火陷材 ${ }^{(633)(634)}$ に圆 するものや，脱酸 S $45 \mathrm{C}^{(635)}$ ，オーステナトイ銅(636), matrixの異なる鋼種 ${ }^{(637)(688)}$, 鉄 ${ }^{(639)}$ などの介在物周辺 のさ裂の観察その他 ${ }^{(640)}$ があり。また結晶精度 ${ }^{(641)}$ (643) や鋳造組織 ${ }^{(044)}$ ，さらには巨視的因子として区延

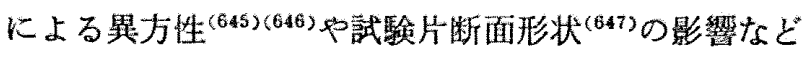
がき裂との関連で㛟討され，き裂先端の局部ひずみの

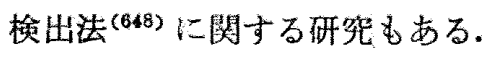

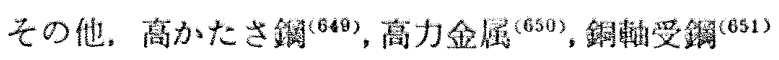

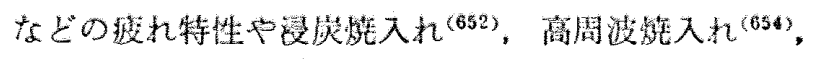

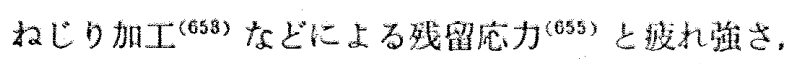

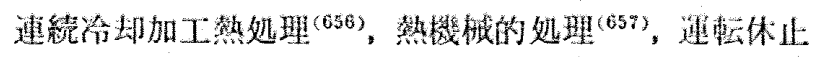

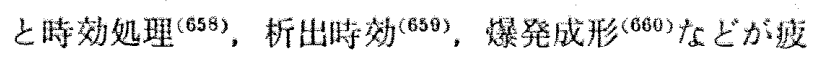

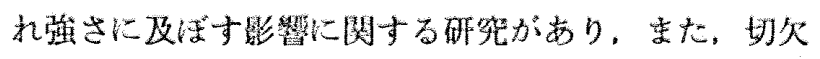

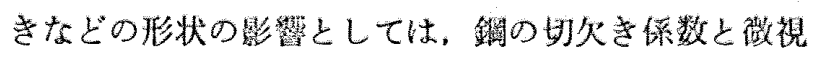

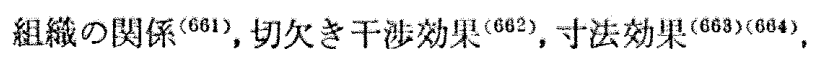
王力容器ノズル取付部の强度 ${ }^{(665)(666)}$, 平极稼形状の

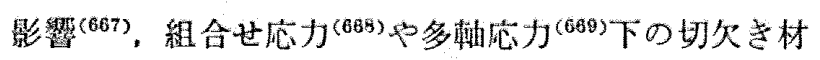

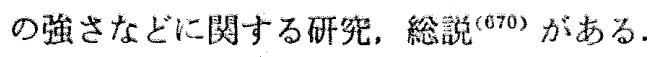

整性瘦れの分野に颃いては，牫留オーステナイト相

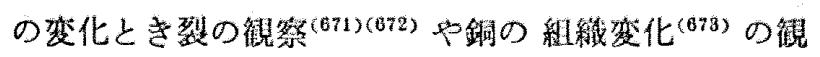

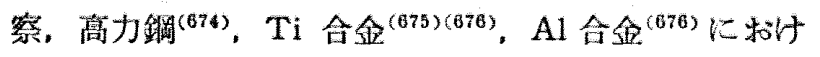

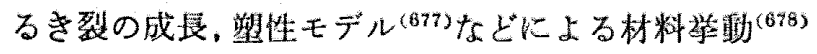

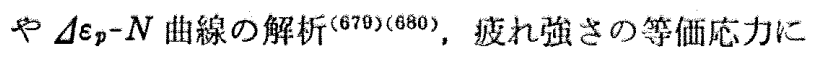
よる整理 ${ }^{(681)}$ ，材料の選定 ${ }^{(682)}$ などに閉する矿究があ

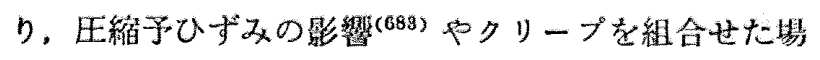
合の举財 ${ }^{(684)(885)}$ 女調べられている.

高低温下の瘦れについては，ステンレス銅(680)(687) の高温波れき裂の進展やき裂测定法 ${ }^{(688)(689)}$, Udimet

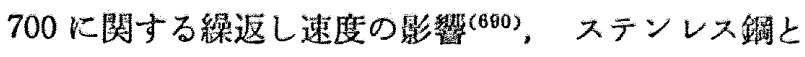

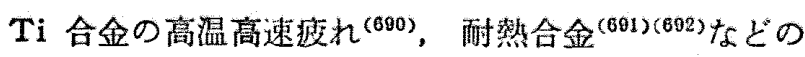
高温疲れ強さなどの听究があり，また，高温強度問題の

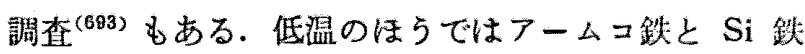
についてへリウム温度までの疫れとぜい性の関係(60s)

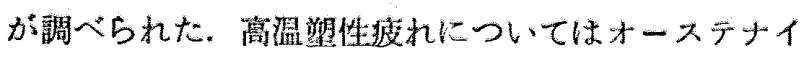

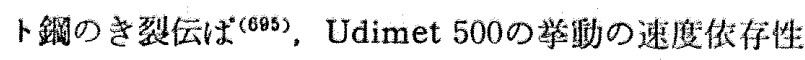

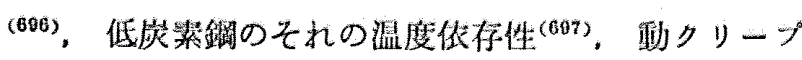

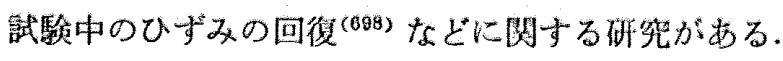

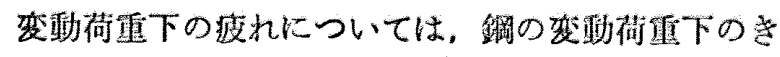

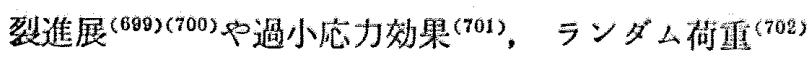

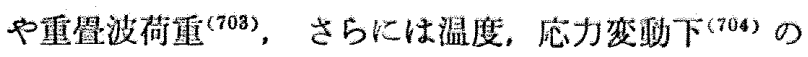

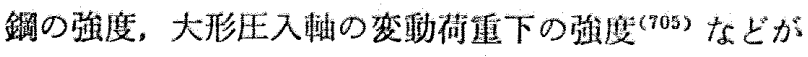
調へられて扣り，末た，不規則街雷のひ儿度解析法 (706)(707) と疫九寿命の推定 ${ }^{(708)}$, 被需とき裂進展亡の圈

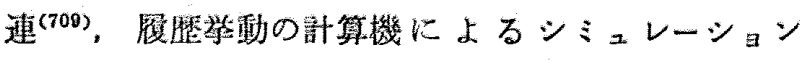

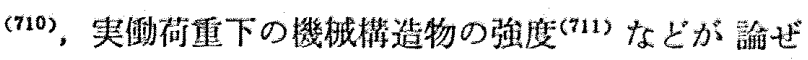
られている.その他，疲れ強さの維的処理と安全設 計については，疲れ限度の統部的分布 ${ }^{(712) \sim(714)}$ とステ ヤケース法 ${ }^{(715)}$, 安全率 ${ }^{(716)}$ と安全性 ${ }^{(717)}$ の㷋狽， $S-N$ 曲線の迅速決定法 ${ }^{(718)}$ な゙゙が市り，はかに，銀の报れ 变形 ${ }^{(79)}$ や銅の変形と内部摩擦(720)の研究がある.

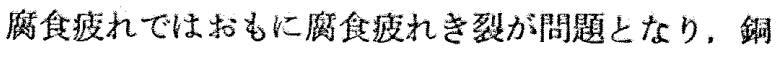

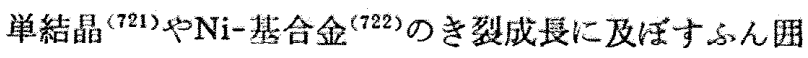

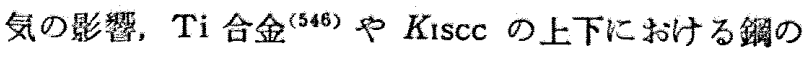




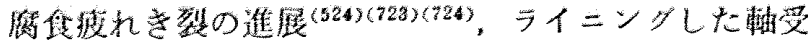

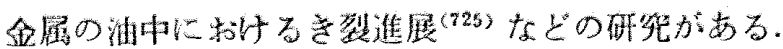

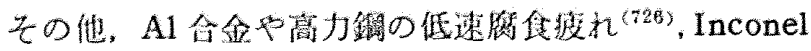

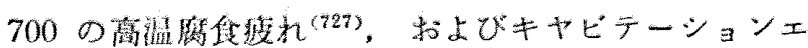

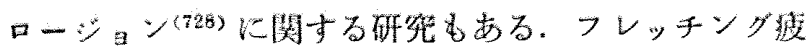

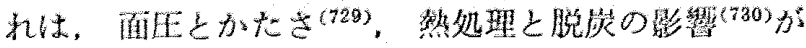

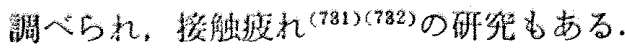

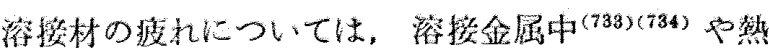

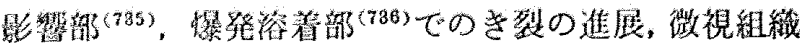

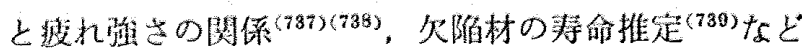

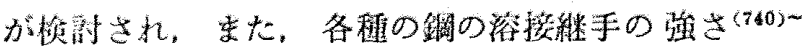

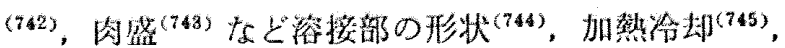
explosive peening ${ }^{(40)}$ などの影留，金の冷間浴接部

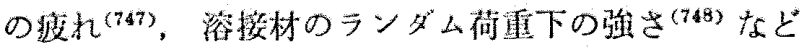

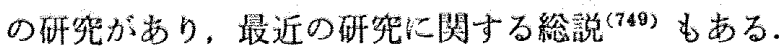

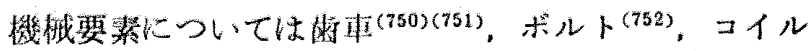

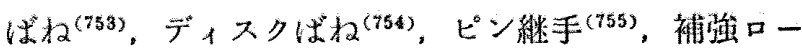

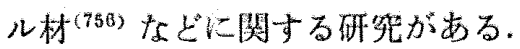

非金屈の高分子材料については FRP(757)，FRTP ${ }^{(758)}, \mathrm{PVC}^{(759)}, ホ^{(00 x チ ル ィ タ ク リ レ イ ト(760), ~ ホ ゚ リ ~}$ カーボネイト(701) などでの疫れさ裂の進展やナイロン

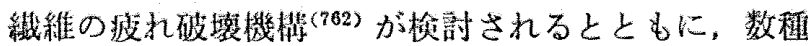

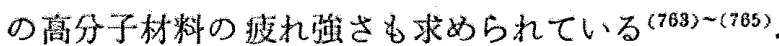
他の材料として迹鉛 ${ }^{(76)}$, 岩石 ${ }^{(767)}$ とついての矿究や プレストレスコンクリート (708) に関する総説がある.

银後に武験装温として, 其振形回転曲け陚験機 ${ }^{(769)}$,

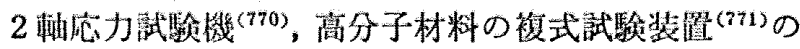

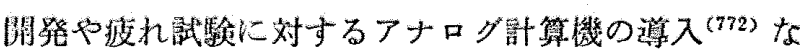

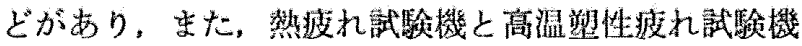
の解梏結果の報告 ${ }^{(773)}$ がある.

[由中道早]

3・3.3 クリーブおよび高温強さ 京都での ICM 材料国際会䋐 (774) 後のエクステンションセミナの一つ として開催された金属の高温疲れおよび耐熱銊の高温 强さと組織に関寸る研究会 ${ }^{(75)}$ においては，金属の㳊 視組䋘の变化と巨視的な機械的性貿をどの上うに定量

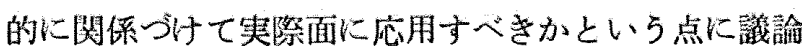
の焦点があったよ5に思われる。

この上5な情謷と閔連して，クリープと高温強さに 開与る分野では，種々の酎熱合金の組織，特に析出物 とクリープ強さの関係についての報告，とりわけわが 国に拈ける研究者の報告が圧倒的に多いことが最近の

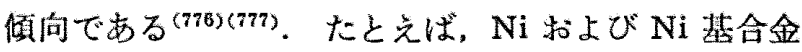

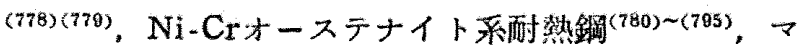
ルテンサイト系耐熱鋼(706)(797)，Ni-Mn マレージング

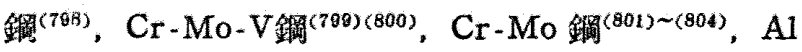
合金 ${ }^{(805)(806)}, \mathrm{Cu}$ 合金 $^{(807)}$ などに閔する報告がある。

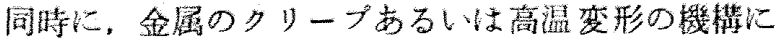

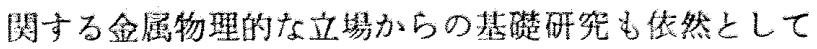

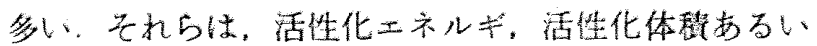

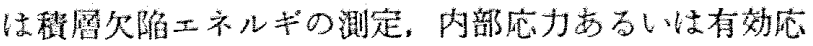
カの推定，電子影微鏡による組織観案などによるクリ

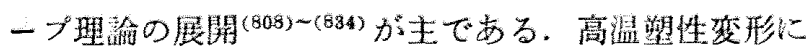

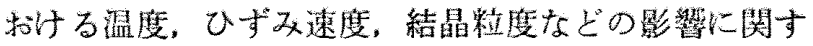
る砸然 (835) (857) む同じ籍ちゅ5にはいる。これら基礎 研究の成果は新しい耐熱材料の開発中耐熱合金の高温 強度性䉢の説明に役立つものであるが，46 年中に発表

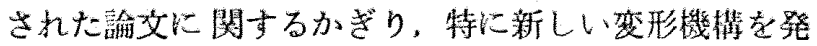
見したり，新理論を提案したものはなく，またこれ らの研究にもとづいて，たとえば変動庆力あるいは変 動盓度下のクリーブ举動を定最的に解析することはい まだ困難なようである。これには变形履歴，温度屋求 に関する研究が必要であろら。この種の理諭的あるい

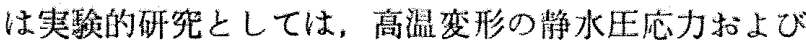

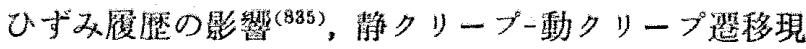
像 ${ }^{(858)(859)}$, 変動応力クリープに関与る㻎詇解析 ${ }^{(860)}$ ${ }^{(662)}$ ，変動庆力・变動温度クリーブの実慗 ${ }^{(883)(864)}$ に関 する報告がある。また，离分子材料については，多重 程分法によるクリーブ变形书よび回復の理諭解析が行 なわれ，奏験結果と比較されている(865) -(867).

クリープカ学については，等方体の定応力クリープ 理論 ${ }^{(808)}$ ，円筒かくのクリーブ幽届 ${ }^{(809)}$ お上び定常ク リープ(870)， FEM のクリープ解析への適用(871) 拉 よび FEMによる切久さクリープの解析 ${ }^{(872)(873)} な と ゙$ の報告がある。また， $\mathrm{Ni}$ 基笚結晶合金の 2 軸庍力ク リープ(874)，低腅素銅切欠さ材のクリーブ応力分布の 濑定 ${ }^{(875)}$ をどの研究がなされている. 要た， A.E. Johnson Memorial Volume としてクリープ設計に 関与る単行本 ${ }^{(876)}$ が出版され，それには，クリープ破 壊の理菕，多軸クリープ、クリープ回後，クリープデ 一タの解析, 高温瘦れとクリーブの閔係、内管のク リープ，部材のクリープ滾䚵などに関する 21 の論文 が集録されている.

以上のほかに，高温に叔ける精界すべりに関する報 告がクリープ(877) (881) 和よび高温引辴 ${ }^{(862) \sim(884)}$ につい てかなりある。これらは粒界の析出物 ${ }^{(885) \sim(887)}$ や䊰界 に発生する空孔 ${ }^{(877) \sim(879)}$ と関係し、クリープに打ける 粒界き裂あるいは粒界破壊の問題(877) (879)(888)(889)の基 礎をなするのである.クリープ破䘫についてはこのほ か心，長時間破断陚験 ${ }^{(800)}$ 队破断データの解析 ${ }^{(891)}$, 破断寿命の外之5法 ${ }^{(888)}$ ，き裂材のクリープ破断強さ ${ }^{(892)}$ ，クリープき裂伝ば速度と応力拡大係数の関係

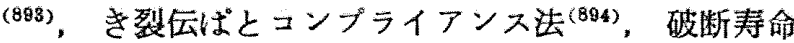




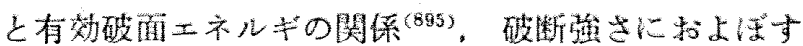

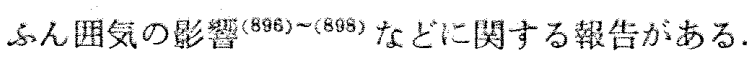

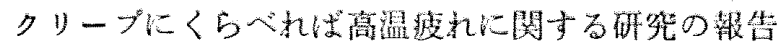

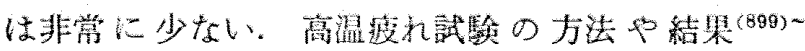

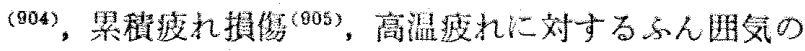

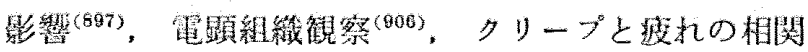

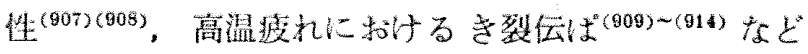

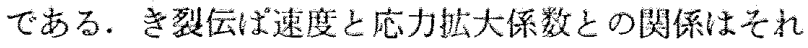
ほどよい結果が得られていないよらである(900) (911).

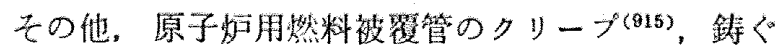

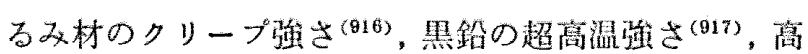

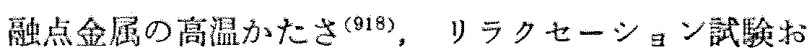
よびデータの解析 ${ }^{(019)}$, S40C の変隹超塑性 ${ }^{(920)}$, FEM による熱弾塑性応力の解析 (921)などが注目される.

\section{(大谷 潐一]}

$3 \cdot 3 \cdot 4$ フラクトグラフィここ数华，ようやくフ ラクトグラフィによる各程破境の矿究が盛儿になり， その発素が多くみられるようになった。かが国のグル 一プ研案活動として機㭜学会関西支部に之の分科会が 㕲かれ，元の座锬会 ${ }^{(922)}$ が倠された。高王力技術会に

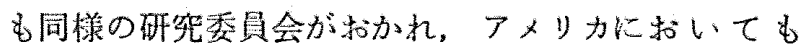
ASTMに小委貝会が括かれている。材料強度と破填 国内総合シンポジムム ${ }^{(023)(024)} に$ にいても近年このテ 一マが一部に取上げられ，立すす一般の関心を高め ている、留近報告された研究の対象となっている材料 お。よび破塐の種類も多く，45，46 年中に発表され。 目に触れたるのについて概钼する。

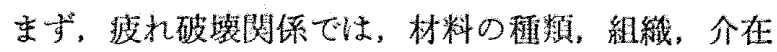
物あるいは无の他の条件による报れき裂の発生ならび に進展に関して破面筧察を行なったもの い. 材料别にみると $\mathrm{Al}$ 合金 ${ }^{(925)(829)(942)(953)}$, $\mathrm{Ni}$ 基超 合金 ${ }^{(\theta 30)(932)(052)(962)}$, Si 鉄 ${ }^{(927)(929)}, \mathrm{Mo}^{(926)}$, マルエ

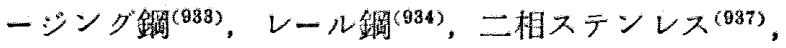
Ti 合金 ${ }^{(958)}, \mathrm{Mg}-\mathrm{Zn}-\mathrm{Zr}$ 合金 ${ }^{(931)}$ など多種類にわた

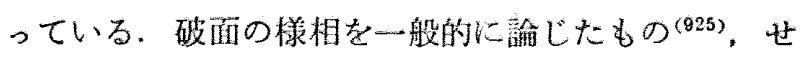
ん断茼重による実呀例 ${ }^{(925)}$, 入き開面 ${ }^{(026)(928)}$, 介在物

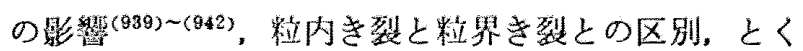

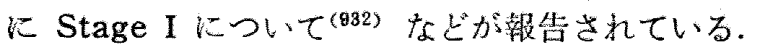

き裂進屡について $K$ 值との閔係を求めたもの

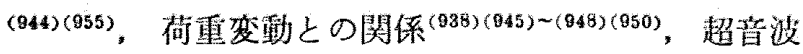
域の速度効果(932)(949)，低+゙クル报れ(950) (952) など

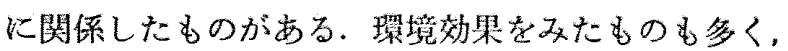
腐食あるいはふん国気の影照(943)(953) (961)をみたもの

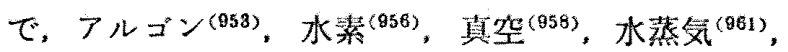
塩水 ${ }^{(954)}$ などの效果について調べられておう，低応力

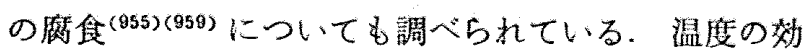

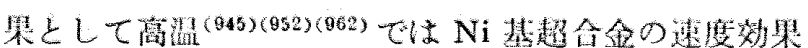

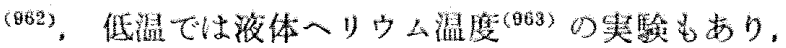

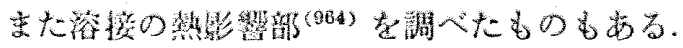

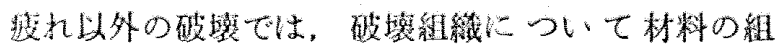

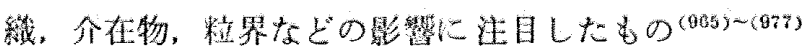

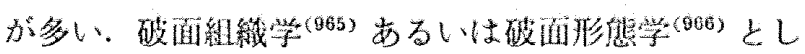

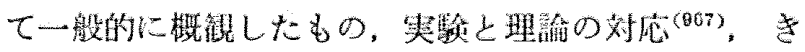

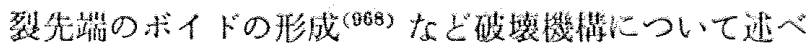

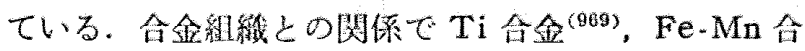

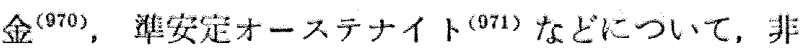
金属介在物の影裂㛭

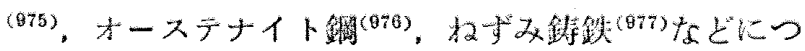

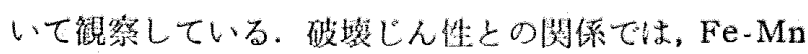

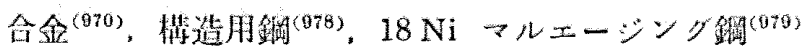

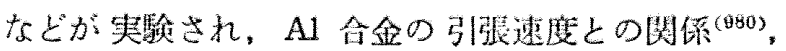

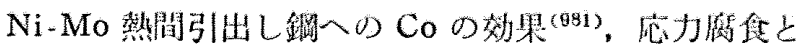

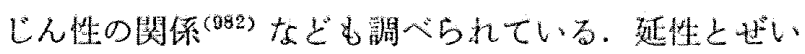
化の比較として Mo 多結晶 ${ }^{(983)}$ について, 王としてせ

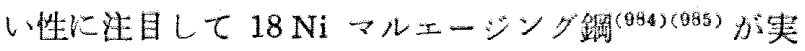

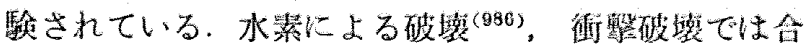
金時效組絨 ${ }^{(987)}$ および非金属介在物の影犁 ${ }^{(972)}$ ，加工

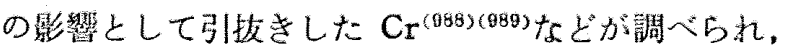

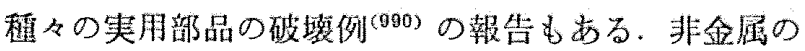

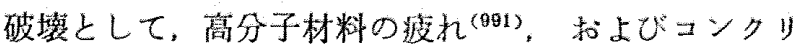

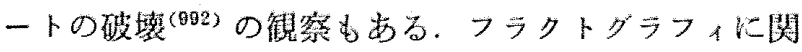

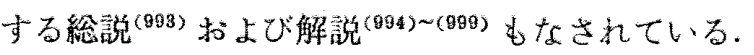

[北川茂]

\section{女献}

(1) 被㬰, 機踰, 37.303 (明 46), 2129. (2) 守，间上，37 304 (⿰ㅖㄹ 46), 2246. (3) Barett, R.F. . 1 38.2(1971), 528. (4) Aderogba, K.V..J. Mech. Phys.

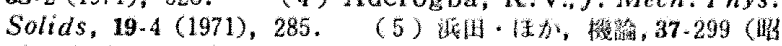
46), 1305. (6) Hussain, M.A., ASME, E, 38.3 (1971), 634. (7) Chan, S.K. - Is, Int.J. Mech. Sci, 13-7 (1971), 615. (8) Chan, S.K. . I (9) Ramachandra, Rao B.S. 性功, ASME, E, 38-3(1971), 705. (10) Deavours, C.A., ibid., E, 383 (1971), 707.

(11) Torvik, P.J., ibid, E, 38-4 (1971), 929. (12) Semple, H.M.・ほjs, Quart.J. Mech. Appl. Math., 24-1 (1971), 115. (13) Singh, B.P. - Ix, Int. J. Solids Struct., 7-11 (1971), 1495. (14) Patra, B., Z.AMM, 51-7 (1971), 564. (15) Pao, Y.C. * bs, ASME, E, 38-3(1971). 608. (16) Engel,P.A., Int.J.Mech. Sci., 13-5 (1971), 391. (17) Conway, H.D., ASME, E, 38-4(1971), 1094. (18)

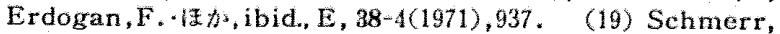
L.W., Z. Angew. Math. u. Phys, 22-4 (1971), 756. (20) Byog, D. B., Int.J. Solids Stract, 7-8 (1971), 993.

(21) Nusayr, A.M.K.·活, ASME, E, 38-4 (1971), 1050. (22) Bhargava, R.D. 蛙和 Non-Linear Mech., 6-3 (1971),

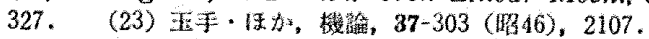

Plato, G. Z AMM, 51-5 (1971), 407 . I.N.・は2, Int. J. Engng. Sci., 9-1 (1971), 25. (26) Stallybrass, M.P., ibid., 9-1 (1971), 133 . (27) Sneddon,

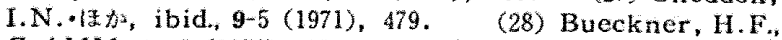
Z. AMM, 51-2 (1971), 97. (29) Kurashige, M., ibid., 51-1 (1971), 52. (30) Ebel, E., ibid, 51-1 (1971), 62.

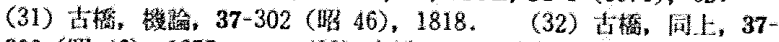

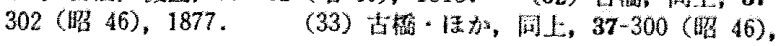




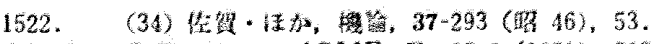

Moghe, S.R. - 18, ASME, E, 38-2 (1971), 393.

Power, L. D., Int. J. Engng. Sci., 9-2 (1971), 241 . (37)

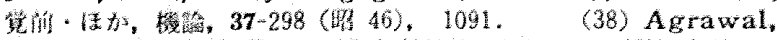
G.L.. 1 is, ASME, E, 38-4 (1971), 906. (39) 土国.

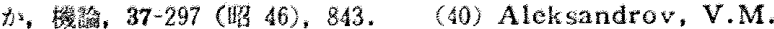
ist, PMM, 35-1 (1971), 53.

(41) Wu, C.-H., ASME, E, 38-4 (1971), 971. (42) Chen,

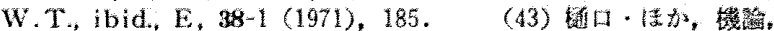
37-297 (昭 46), 869. (44) Chen, W.T.. Int. J. Engng. Sci., 9 9 (1971), 775. (45) Bondareva, V.F., PMM, 35

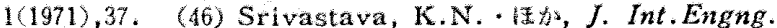
Sci, 9-3 (1971), 399. (47) Smith, E., ibid, 9-7(1971), 631. (48) Clements, D.L., ibid., 9-2 (1971), 257. (49) Green, A.E. - 数, Proc. Camb. Phil. Soc, 69-1 (1971), 227 . (50) Crochet, M.J., Int. J. Solids Struct., 7-4 (1971), 383. (51) leçan, D., Int. J. Engng. Sci., 9-1 (1961), 59. (52) Ieçan, D., ibid. 9-10 (1971), 879 . (53) Stouffer, D.C. $A S M E, \mathrm{E}, 38-2(1971), 548 . \quad$ (54) Sun, C.T., ibid. E, 38-4 (1971), 947. (55) Roger, T.G.・ほか, ibid, E,

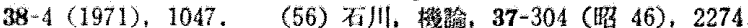
(57) Biricikoglu, V., ASME, E, 38-4 (1971), 1095. Parnes, R, Int. J. Mech. Sci., 13-4 (1971), 285. Huddleston, J, V., ASME, E, 38-4 (1971), 942.

Rao, B.S.R. . 畋为, ibid., E, $38-3$ (1971), 705 .

(61) Perakotte, G.J. - (1) מ, ibid., E, 38-4 (1971), 1036

(62) Reisner, E.·泳, Int. J. Solids Struct., 7-6 (1971), 625. (63) Hubbert, L.E. 929. (64) Hsu, Y.S., J. Franklin Inst., 291-4(1971), 255 (65) Sun, C.T., ASME, E, 38-1 (1971), 231. (66) Chen, Y.N.・偠か, ibid., E, 38-4 (1971), 964. (67) Pyyor, C.N.・㤬加, AIAA J., 9-4 (1971), 912 . (68) Green,A.E. 任加, Proc. Camb. Phil. Soc., 69-1 (1971), 227. (69) Whitney, J.M., ASME, E, 38-2 (1971), 530. boune, A.N. ・ Es, Int. J. Mech. Sci., 13-3 (1971), 231.

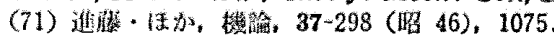
71), 231 . (73) Adams, W.J.I.,

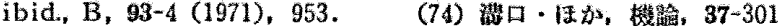
(明 46), 1457. (75) 半沢・ ほ加, 同上，37-301 (昭 46), 2053.

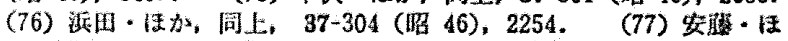
办, 同上，37-294 (昭 46)，237。 (78) 安荫·保加, 同上, 37294 (昭 46), 1803. (79) Gwatney, R.G.・12, ASME, B., 93-4 (1971), 986. Struct. 7-12 (1971), 1653

(81) Bond, M.P. - $\$$ to, J. Strain Analysis, 6-2 (1971), 77. (82) Bond, M.P.•lか, ibid., 6-4 (1971), 213. (83)Bond, M.P.・放, Int. J. Mcch. Sci., 18-5 (1971), 471. (84) Smith, T.A., AIAA J., 9-4 (1971), 634. N. 浑加, ASME, B, 93-4 (1971), 1030.

(85) Nelson, (86) Shalfer

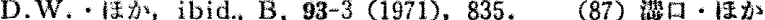

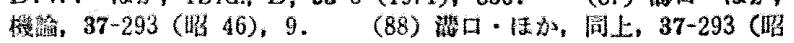

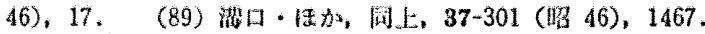

(90) Zukas, Z.A.・恬办, ASME, E, 38-2 (1971), 400.

(91) Morino, L. · 1 加, ibid, E, 38-2 (1971), 423.

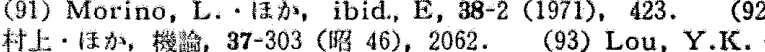
19, ASME, E, 38-2 (1971), 408. (94) Perrone, N. Is, ibid., E, 38-2 (1971), 371 . Int. J. Engng. Sci., 9-10 (1971), 889 95) Faulkner, T.R. (96) Gwaltney,

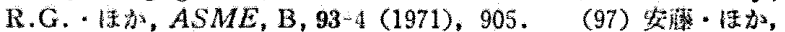

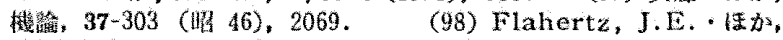
AIAA J., 9-9 (1971), 1725. (99) Tielking, J.T.・ ASME, E, 38-2 (1971), 418. (100) Wemper, G.A., Int. J. Solids Struct., 7-11 (1971), 1581.

(101) Krajcinorie, D., ibid., 7-6 (1971), 559.

(102)

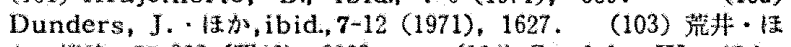

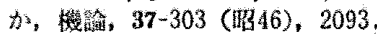
ASME, B, 93-3 (1971), 765 . ibid., B, 93-3 (1971), 851 . ibid., B, 93-4 (1971), 1016. (104) Soedel, W. (105) Lomacky, O.・略, (106) Lavsen, R.K. - ( (107) König, J.A., Int. J. Solids Struct, 7-4(1971), 327. (108) Roberts, T.M. 疗加,

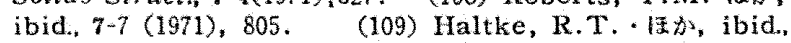

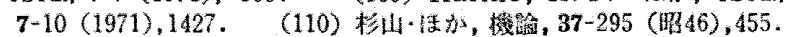

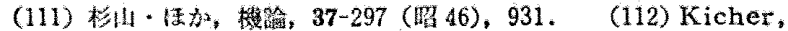
T.P.・注法, AIAA J, 9-4 (1971), 605. (113) Brunelle. E. J., ibid., 9-6 (1971)， 1018. (114) 杉山・年加, 機路, 37296 (昭 46), 641. (115) Amazigo, J.C., Int. J. Solids Siruct., 7-8 (1971), 883. (116) Narasimhan, K.Y.・ほ两, ASME，E，38-1 (1971)，160. (117) 枓封・活办，機踰。 37-298 (昭 46), 100 . (118) Flügge, W.・ほ文, Int. $J$. Solids Struct., 7-8 (1971), 1109 . (119) Pan, Y.S., ASME, E, 38-1 (1971), 209 . (120) Murphy, L.M.・ほか, Int.
J. Solids Struct., 7-9 (1971), 1153.

(121) Honikman, T.C., ibid, 7-12 (1971), $1685 . \quad$ (122)

Stephens, W.B., AIAA J., 9-9 (1971), 1713. Alexander, H., Int. J. Mech. Sci, 13-2 (1971), 87. (124) Kao, R. W ASME, E, 38-1 (1971), $172 . \quad$ (125) Thurston, G.A., ibid., E, 38-1 (1971), 179. (126) Akkas,

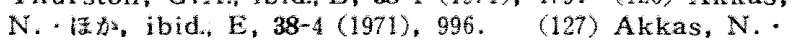
I.⿻. Tennyson, R.C.·㥪为, AIAA J., 9-2 (1971), 250. (129) Feinstein, G. - 传方, ibid., 9-9 (1971), 1733. Akkas, A.・施, Int. J. Mech. Sci., 13-8 (1971), 689. (131) Almroth, B.O. - AIAA J., 9-1 (1971), 32. (132) Das, B.R., Int. J. Engng. Sci., 9-5 (1971), 469. (133) Srivastava, K.N.・名, Z.AMM, 51-6 (1971), 433. (134) Kassir, M.K., ASME, D, 93-4 (1971), 643. (135) Verruijt, A., Z. Angew. Math. Phys., 22-5 (1971), 891. (136) Karlekar, B.V., ASME, E, 38-4 (1971), 834. (137) Yang, K.W. - W bs, ibid., B, 93-4 (1971), 969. (138)

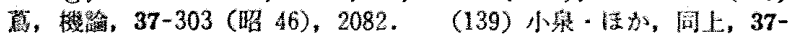

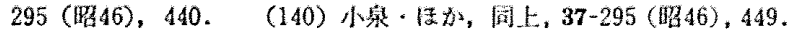
(141) Cher n, J.M., ASME, E, 38-2 (1971), 538 . Choudhuri, S.K.R., ibid., E, 38-1 (1971), 277. (142) Lin, T.D. •ほ Proc. ASCE, 97-EM 3 (1971), 829.

(144) Bushnell, D. ・活, AIAA J., 9-12 (1971), 2314, (145) Fisher, H.D., ibid, 9-5 (1971), 977. (146) 溸口, 機緰，37-298 (昭 46), 1107. (147) Hannon, B.M., ASME, B, 93-4 (1971), 913. (148) Tao, L. N., Int. J. Engng. Sci.. 9-5 (1971), 489 . (149) Kline, K.A.・伍, Int. J. Sötids Struct., 7-2 (1971), 129. (150) Stroud, R.C. - \& מ, AIAA J., 9-1 (1971), 76 .

(151) Percival, C.M., ibid., 9-2 (1971), 347.

Gauster, W. B., J. Mech. Phys. Solids, 19-3 (1971), 137. (153) Sve, C., Int. J. Solids Struct. 7-10 (1971), 1363. (154) Gurney, T.R. J. Strain Analys.; 6-2 (1971), 89. (155) Stevens, D.W.・主, Nuclear Sci. Engng., 45-1(1971), 73. (156) Armstrong, R.W.・五, Metallurgia Trans, 2-11 (1971), 3073. (157) 山口, 機站, 74-631 (昭 46), 951. (158）中平, 闹上, 74-627 (昭 46), 402. (159) Chow, C.L,

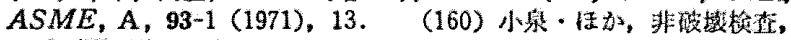
20-3 (暗 46), 148 .

(161) Bush, A.J., Exp. Mech., 11-2 (1971), 87. (162) David, T.J., ibid., 11-4 (1971), 185 . (163) 武井・活加, 非

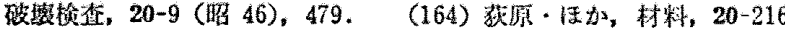
(昭 46), 1031. (165) Chong, K.P.・渒, J. Acous. Soc. Amer., 49-1(1971), 201. (166) 田中·恬战, 機䟺, 37-303(嚾46), 2114. (167) Bolleter, U. • 㴽加, J. Acous. Soc. Amer. 49-3 (1971), 753. (168) Yu, J.C.M., ibid., 49-3(1971), 230. (169) Liao, E.N.K.·潘, ASME, E, 38-4 (1971), 978. (170) Schiffner, K.・12加, AIAA J., 9-1 (1971), 37.

(171) Longcope, D.B. $ほ W^{2}$, ibid., 9-2 (1971), 339. (172) Mazalov, V.N. - I 111. (173) Lou, Y.K.・湫, ASME, E,38-2 (1971), 408. (174) Bulanowski, E.A., Jr.. $\cdot$ (1) (175) Gahenheimer, D.C., ibid., 38-1 (1971), $99 . \quad$ (176) Schmerr, L.W., Jr., •ほか, ibid., 38-4(1971), $1076 . \quad$ (177) Norwood, F.R., ibid, 38-2 (1971), 549. (178) Freund, L. B., ibid., 38-4 (1971), 899 . (179) Tsai, Y.M., Int. J. Solids Struct. 7-6 (1971), 543. (180) Acharya, H. K.J. Acous. Soc. Amer., 50-1 (1971), 172.

(181) Awojobi, A.O. ASME, E, 38-1 (1971), 111.

Warburton, G.B. - 2 As, ibid., 38-1 (1971), 148. Scavuzzo, R.J., ibid., 38-1 (1971), 125 . (184) Keer, L. M.・はか, ibid., 38-1 (1971), 92. (185) Itou, S.・はか, Int. J. Engng. Sci., 9-12 (1971), 1209. (186) Thau, S.A - Es, Int. J. Solids Struct., 7-7 (1971), 731. (187) Mura, T., Phil. Mag., 23-181 (1971),235. (188) Nowacki, W. Z. AMM, 51-Sonderheft (1971), 1. (189) Valanis, K.C., Arch. Mech., 23-4 (1971), $517 . \quad$ (190) Valanis, K.C., ibid., 23-4 (1971), 535.

(191) Perzyna, P., Int. J. Non-Linear Mech., 6-6 (1971), 707. (192) Rice, J.R., J. Mech. Phys. Solids, 19-6 (1971), 433. (193) Green, A.E.・传加, Int. J. Engng. Sci., 9-12 (1971), 1219. (194) Кунеев, В.И., ·ま, Мех. maếp. mела, 5 (1971), 90. (195) Русинко, К.Н., ibid., 6 (1971), 37. (196) Костюк, А.Г., ibid, 2 (1971), 12. (197) Havner, K.S., Int. J. Solids Struct., 7-7 (1971), 719. (198) Havner, K.S., ibid, 7-9 (1971), 1269. (199) Нилл, P., Пркил, жат. нex, 35-1 (1971), 31. (200) Jones, W.J.D. ・ E 1 , J.Strain Analys.. 6-3 (1971), 185.

(201) 阿部, 機䠼, 37-296 (蛁46), 633. (202) Owen,D.R.J. Int. J. Non-Linear Mech., 6-2 (1971), 167. (203) Mura, 
T., ASME, E, 38-4 (1971), 865. (204) Eisenberg, M.A. 12, Acta Mech, 11-3/4 (1971), 247. (205) Mulcahy. T.M. ASME, D, 38-4 (1971), 869 . (206) Tokuoka, T., Arch. Rat. Mech. Anal., 42-4 (1971), $239 . \quad$ (207) Hadiow, J.B. 情放, Int. J.Non-Linear Mech., 6-4 (1971),

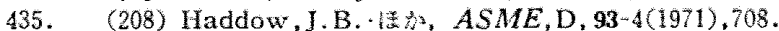
(209) Williams, J.F.. 隹为, J. Strain Analys., 6-4 (1971), 263. (210) Pascoe, K.J., ibid., 6-3 (1971), 181.

(211) Андреев, Л.С., Мех. mөвр. тела, 4 (1971), 143. (212) Krempl, E., ASME, D, 93-2 (1971), 317.

Wierzbicki, T. Acta Mech, 12-1/2 (1971), 21.

Frederking. R.M.W. . (215) Данилов, В.Л., Мех. теЕр. тела, 5 (1971), 146. (216) Chu, T.Y.・活放, Int. J. Engng. Sci., 9-10 (1971), 971. (217) DeRuntz, J.A., Jr., ASME, E, 38-1(1971), 23. (218) Lance, R.H. - 传粼, J. Mech. Phys. Solids, 19-2

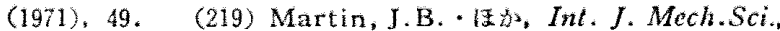
13-3 (1971), 195. (220) Ponter. A., ASME, E, 38-2 (1971), 437 .

(221) Maier, G., Int. I. Solids Struct, 7-4 (1971), 345. (222) Ho, H.S., ASME, E, 38-4 (1971), 852.

Epxoв, M.И., Mex. moép. meлa, 2 (1971), 26. Wierzbicki, T., J. Mech. Phys. Solids, 19-1 (1971), 1.

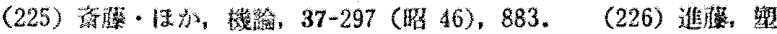

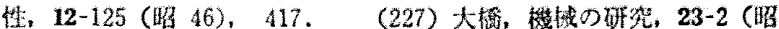
46). 343; 23-3 (昭 46)，479；23-4 (昭 46), 611. (228) 大献・ 淁为，籿料，20-210 (昭 46)，236. (229) Swedlow, J.L. 传加, Int. J. Solids Struct., 7-12 (1971), 1673. (230) Wempner, G.A., ibid, 7-11 (1971), 1581.

(231) Hofmeister, L.D. . 汪加, AIAA J., 9-7 (1971), 1248. (232) Wilson, E.A., ASME, B, 93-3 (1971), 793. (233) Larsen, P.K. . 活加, ibid., B, 93-4 (1971), 1016. (234) Popov, E.P. - 淁加, Int. J. Num. Meth. Engng., 3-4(1971),

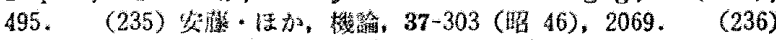
Lomacky, O.P保, ASME, B, 93-3 (1971), 851. (237) Солодовников, В.Н., Мех. төёр. тела, 3 (1971), 109. (238) Gerdeen, J.C. -ほ\$, AIAA J., 9-6 (1971), 1012. (239) Лнстрова, Ю.П., - \$, Мех. твёр.mела, 2 (1971), 59. (240) Muensterer, H.F.* 注加, J. Strain Analys., 6-4 (1971), 273.

(241) DeBoer, von R., Z.AMM, 51-8 (1971), 627 (242) Yeh, G.C.K., Int. J. Non-Linear Mech., 6-3 (1971), 393. (243) Korol, R.M., Int. J. Mech. Sci., 13-8 (1971), 681. (244) Pascoe, K.J., J. Strain Analys., 6-3 (1971), 167. (245) Celep, Z.・活加, Ing.-Arch., 40-3 (1971), 188. (246)

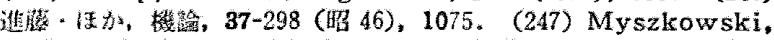
J., Ing. Arch., 40-1 (1971), 1. (248) Sherbourne, A.N. Is, Int. J. Mech. Sci, 13-3 (1971), 231. (249) Srivastava, N.K. * 2 极, Proc. ASCE, 97-EM1 (1971), 13. (250) Palazotto, A.N.・汪, Int.J.Mech.Sci., 13-2(1971), 97. (251) Bovie, O.L. - ほ (252) Будянскнй, Б., Прикл. мат. мех., 35-1 (1971), 40. (253) Линьков, А.М., Мех. төёр. mела, 1 (1971), 80. (254) Chakrabarty, J., Int: J. Mech. Sci., 13-5 (1971), 439. (255) Hardy, C. - ま加, Int. J. Num. Meth. Engng., 3-4 (1971), 451. (256) Dumas, G.・\&か, Int. J.Mech. Sci., 13-6 (1971), 519. (257) Luxmoore, A.R.・活, J. Mech. Phys. Solids, 19-6 (1971), 395. (258) Grifiths, J.R.

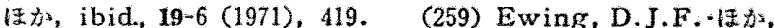

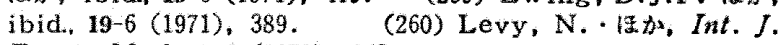
Fract. Mech., 7-2 (1971), 143.

(261) Glennie, E.B., J. Mech. Phys. Solids, 19-5 (1971), 255. (262) Chitaley, A.D. - 隹か, ibid, 19-3 (1971), 147 . (263) Atkinson, C., Int. J. Engng. Sci, 9-8 (1971), 729. (264) Ridha, R.A.-ほ加, Proc. ASCE, 97-EM 3 (1971), 773. (265) Baronas, R.P., Int. J. Num. Meth. Engng. 3-3 (1971)，415. (266) 石川, 機緰, 37-304 (昭 46), 2274。 (267) Gambin, W. 泟加, Arch. Mech., 23-6 (1971), 765. (268) Burnat, M., ibid., 23-6 (1971), 817 (269) Fox, N.o J. Mech. Phys. Solids, 19-5 (1971), $245 . \quad$ (270) Besdo, D., ibid., 19-6 (1971), 313 .

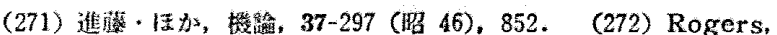
H.C. ·程, Int. J. Mech. Sci. 13-2 (1971), 141. (273) Tirosh, J., J. Mech. Phys. Solids, 19-1 (1971). 39. (274)

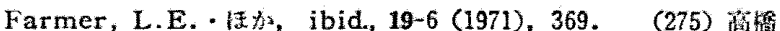
- ほ象, 整性, 12-121 (昭 46), 122. ASME, B, 93-2 (1971)586. Mech. Sci., 13-4 (1971), 345. (276) Shabaik, A.H., (277) Robinson, M., Int. J. J. Solids Struct., 7-8 (1971), 1057. ほか, ASME, B, 93-4 (1971), 998. (280) Schroeder.
(279) Ho, H.S. -
J.-12, Proc. ASCE, 97-EM1 (1971), 63

(281) Morris, A.J., Int. J. Num. Meth. Engngs. 3-2(1971), 215. (282) Morris, A.J. . 传加, Int. J. Mech. Sci, 13-1 (1971), 331. (283) Kônig, J.A., Int. J. Solids Struct. 7-6 (1971), 327. (284) Das Talukder, N.K. - 估粦, Arch Mech. 23-3 (1971), 353 . (285) Chan, H.S.Y. Int.J

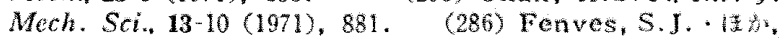
Int. J. Num. Meth. Engng., 3-3 (1971), 425. (287) Johnson, W. 在波, Int. J. Mech. Sct., 13-6 (1971), 547 . (288) Gjolsvik, A., Int. J. Solids Struct., 7-10 (1971), 1411. (289) Martin, J.B., ibid., 7-1 (1971), 63. (290) Reiss, R. - 滛敋, ibid., $7-6$ (1971), 603 .

(201) Gajewski, A. - 传名, Arch. Mech., 23-2 (1971), 147.

(292) Chen, W.H., Int. J. Solids Struct, 7-7 (1971), 685 (293) Miles, J.P., J. Mech. Phys. Solids, 19-2(1971), 89 (294) Cheng, S.Y. . Mts, Quart. Appl. Math. 29-1 (1971) 41. (295) Storákers, B.. I. Mech. Phys. Solids, 19-6 (1971), 339. (296) Murphy, L.M. * Struct. 7-9 (1071), $1153 . \quad$ (297) Wang, S.S.K. . 1 . 3 , Proc. ASCE, 97-EM 1 (1971), 77 (298) Kantor, B. Ya., Arch. Mech., 23-1 (1971), 37. (299) Шаповалов, Л.А., Прижл. меm. нах., 35-2 (1971), 206. Ramsey, H. 政, Quart, Appt, Math., 28-4 (1971), 473. (301) Wojewódzki, W., Arch. Mech., 23-1 (1971), 73. (302) Samanta, S.K., J. Mech. Phys. Solids, 19-3 (1971),

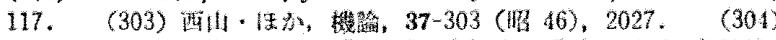
Hawkyard, J.B. - 尔, Int. J. Mech. Sci., 13-2 (1971), 171. (305) Balendra, R. . Fs, ibid., 13-6 (1971), 495. (306) Valathur, M. ·被办, ASME, E, 38-2 (1971), 555.

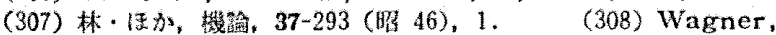
J.G., ASME, D, 93-4 (1971), 478. (309) Jahsman, W.E. ibid, E, 38-1 (1971), 75. (310) Duffy, J. ·It, ibid, 38-1 (1971), 83 .

(311) Rabotnov, Yu. N.・湾, Int. J. Solids Struct, 7-2 (1971), 143. (312) Работнов, Ю.Н. . 㴽加, ПрикA, sam. мex, 35-1(1971), 20. (313) Суворова, ЮО.В., Мех.mвёp. mesa, 2 (1971), $18 . \quad$ (314) Kelly, J.M., Int. J. Solids

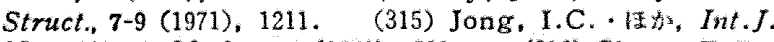
Non-Linear Mech., 6-4 (1971), 511. (316) Shaw, R.P. ほか, ASME, E, 38-1 (1971), 47. (317) Taulbee, D.B. . ほか, Int. J. Non-Linear Mech., 6-1 (1971), 27. Ting, T.C.T. ASME, E, 38-2 (1971), 441. (319) Tuschak, P.A.症, ibid., 38-4 (1971), 888. Morland, L. W. J. Mech. Phys. Solids, 19-5 (1971), 295. (321) Безгласный, Г.А., 便功, Мех.mвёр, mела, 5 (1971), 71. (322) Goel, R.P.・忹办, ASME, E, 38-4 (1971), 895.

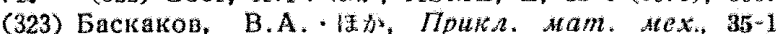
(1971), 71. (324) Raniecki, B., Quart. Appl. Math, 292 (1971), 277. (325) Murakami, S. - 127s, Arch. Mech.. 23-2 (1971), 199. (326) Cristescu, N., Rev. Roum. Sci. Tech., Méc. Appl., 16-4 (1971), $797 . \quad$ (327) Jlumae日, A

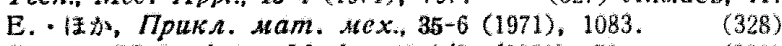
Shack, W.J., Acta Mech., 12-1/2 (1971), 71. Youngdahl, C.K. Int. J. Solids Struct, 7-9 (1971), 1127. (330) Green, R.J., Proc. ASCE, 97-EM 2 (1971), 413. (331) Aggarwal, H.R. - Iats, Int. J. Non-Linear Mech 6-1 (1971), 69. (332) Johnes, N., Int. J. Soltds Struct., 7-8 (1971), $1007 . \quad$ (333) Batra, R.C. $\cdot 12$ w, ibid., 7-8 (1971), 965. (334) Calder, C.A. . 19 s, ibid, 7 9 (1971) 1143. (335) Jones, N.. ED, Int. J. Mech. Sci., 13-8 (1971), 721. (336) Calder, C.A. - ほt, Int. J. Solids Struct., 7-7 (1971), 863. (337) Duffey, T. A., Acta Mech., 11-1/2 (1971), 45. (338) Lal, G.K. - 1 \%, ASME, D, 93-4 (1971), 681. (339) Morino, L..12, is, ibid, E, 382 (1971), 423, 429. (340) Perrone, N., Proc. ASCE, 97 EM 1 (1971), 49

(341) Toridis, T.G. ・ 镂加, ibid., 97-EM 3 (1971), 847. (342) Wu, R.W.H. ・ほか, AIAA J., 9-9 (1971), 1719. (343) Save, M.A. 情及, Plastic Analys. and Des. of Plates, Shells and Disks, (1971), Horth-Holland. (344) Heyman, J., Plastic Des. of Frames, 2 (1971), Cambridge.

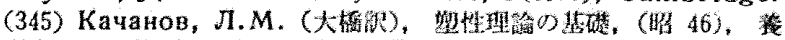
堅裳. (346) Adler, A.J., Exp. Mech. 11-8 (1971), 378 . (347) Valentich, J., ibid., 11-12 (1971), 569. (348) 聯迆.

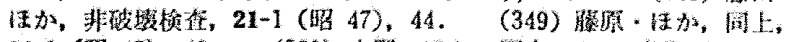

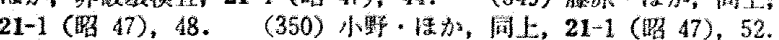

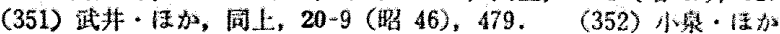

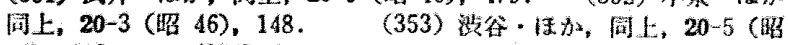
46), 246. (354) Derenne, M. - 汪, Exp. Mech., 11-3 (1971), 105. (355) Crawford, J.C., ・注方, ibid., 11-4 
(1971), 145. (356) Leasure, W.A. 13.7, ibid., 11-5(1971). 235. (357) Andreac, $\mathrm{G}_{\text {, }}$ Material prufung, 13-4 (1971),

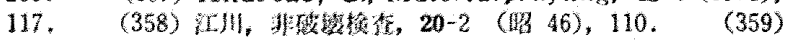

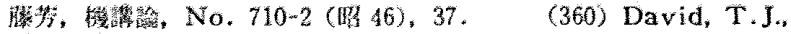
Exp. Mech., 11 4(1971), 185.

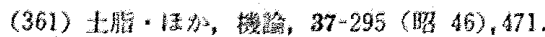
(362) Shuck, L.Z.・铸\%, Exp. Mech., 11-6(1971), 276 . (363) Bayer, R.G. - 12, ibid, 11-10 (1971), 461. (364) Dally, J.W

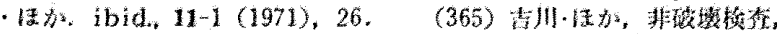

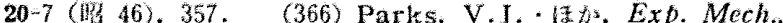
11-1 (1971), 33. (367) Shibata, I. 情, Materialprüfung 13-5(1971), 163. (368) Bohler, P..17, Exp.Mech.11-7(1971), 289. (369) McNicholas, J.B. Strain, 7-1 (1971), 20. (370) Fishburn, J.D. Ho, Exp. Mech., 11-12 (1971), 554 (371) Parmerter, R.R. + ist, tbid, 11-9 (1971), 414. (372) Segerlind, L.J. • |zt), ibid, 11-10 (1971), 440

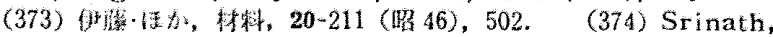
L.S.,Exp. Mech., 11-3 (1971), $130 . \quad$ (375) Aderholdt, R.W. - (376) Dally, J.W.

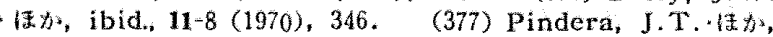
ibid. 11-3 (1971), 113. (378) Schumann, W. + la

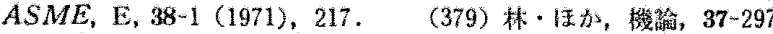

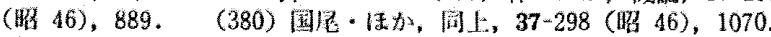

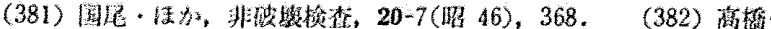
(E), Iat L, 20-7 (II3 46), 368. (383) Boone, P.M., Exp. Mech., 11-11 (1971), 481. (384) Post,D. - lat, ibid., 1111 (1971), 408. (385) Caluwe, M. . 楼, Strain, 7-1 (1971), 15. (386) Luxmoore, A.R. . Ka, Exp. Mech. 11-8 (1971), 375. (387) Chiang, F.P. . is, ibid. 11-7 (1971), 296. (388) Dhir, S.K. * is, ibid. 11-12 (1971) 560. (389) Brinson, H.F., ibid, 11-10 (1971), 467. (390) O'Regan, R. . 14, ibid., 11-6 (1971), 241

(391) Sciammarella, C.A.. * $\%$, ibid. 11-3 (1971), 97 (392) Sanford, R.J.・If, ibid. 11-4 (1971), 161. (393) Aprahamian, R. • / 2 , ibid., 11-7 (1971), 309. Aprahamian, R.

Wilson, A.D.·諉出, ibid., 11-5(1971), 229. (396) Pryor T.R. 理林, ibid., 11-12 (1971), 565. (397) X.Ray Study on Strength and Deformation of Metals, (1971), JSMS.

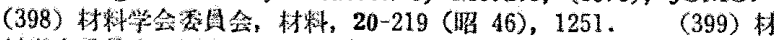

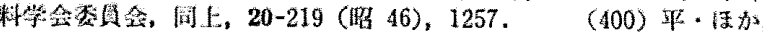
Ht $1,20-219(174,46), 1320$.

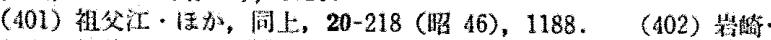

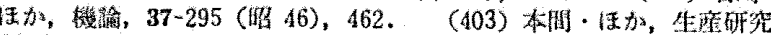

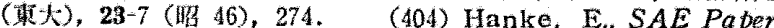
No. $710279(1971), 1-8$. (405) Wegmueller, C.R., Metal Progr., 99-5 (1971), 66. (406) Kirk D. Strain, 7-1(1971),7.

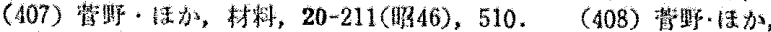

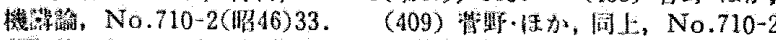

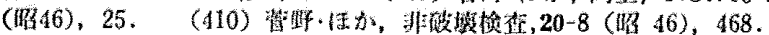
(411) Abuku, S. . 1f, Exp. Mech, 11-5 (1971), 217

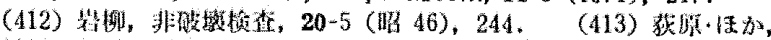

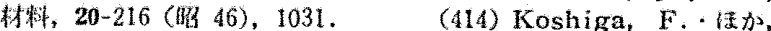

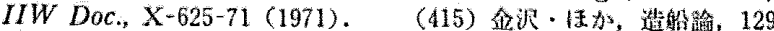

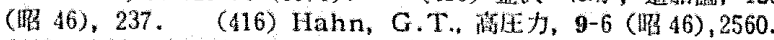

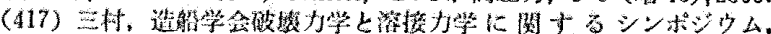
(暗 46)，16. (418) Begley, J.A.注办, 5 th Nat.Symp. Fract. Mech. 1971, (ASTM-STP $<$ C Hilton, P.D. Lehigh Univ. IFSM-71-5 (1971). Chitaley, Ifts, J. Mech. Phys. Solids, 19 (1971), 147.

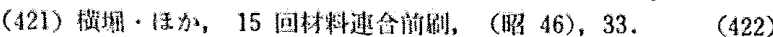
Heyer, R.I.. - Is, 4th \& 5th Nat. Symp. Fract. Mech. (1969, 1970). (423) Liu, A.F. 情, , Proc. Ist Int.Conf. Mech. Beh. Mat..1971, (1972). (424) Hahn, G.T. . 14, Engng. Frac. Mech., 2-3 (1971), 273. (425) Ishida, M., Proc. 1st Int. Conf. Mech. Beh. Mat., 1971, (1972).

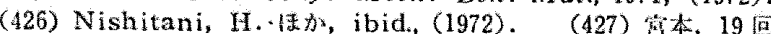

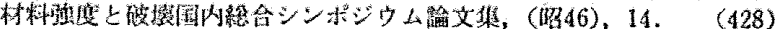
楼场, 同上, $\left(\mathrm{O}_{3} 46\right), 72$. Mech., 11 (1971), 1 . Fract. Mech., 6-1 (1971), 41

(431) Gavigan, \&\$, ASME Paber, 71-PVP-52 (1971). (432) Levy, N..I2, Int. J. Fract. Mech., 7-2 (1971), 143. (433) ISI Publication 120 (1970) \$Metal. Trans.

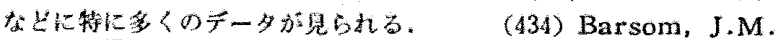
- 传和, Engng. Fract. Mech., 2-4 (1971), 341.

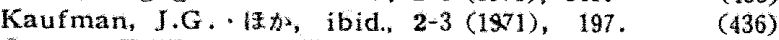
Orange, T.W. * W, NASA TN, D-6305 (1971). (437) Proc. Conf. Appl. Fract. Mech. Press. Vess. Tech. (1971) の整甾女. (438) Kaufman, J.G., DeSalvo, G.J., Underwood, J.H. Maxey, W.A. I., 5 th Nat. Svmp. Fract.

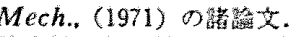

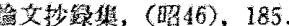
Mech., 2-2 (1970), 125.

(441) Clark, W G., ibid, 2-4(1971), 287. (442) Orange, T.W., ibid., 3-1 (1971). is, NASA TN, D-6054 (1970). (444) Shah, R.C., Kobayashi, A.S., Marrs, G.R. - ifs, Grandt, A.F.-Sinclair,

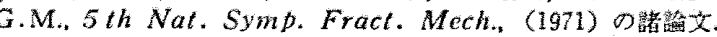

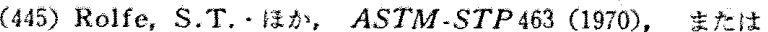
ASTM-STP 466 (1971). Rep., WVT $-7044(1970)$ (446) Kendall, D.P., Tech. 4, (485) Haw thorne,

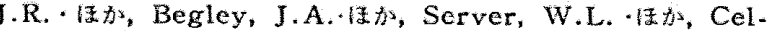

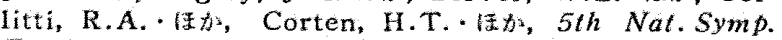

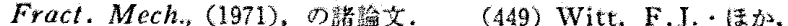
ibid., (1971). (450) Weitzmann, R.H. - ほt, Proc. 1st Int. Conf. Mech. Beh. Mat., 1971, (1972).

(451) Wilson, W.K., Engng. Fract. Mech., 2-2 (1970), 169.

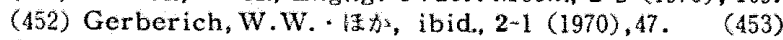
Gallagher, J.P., ibid, 3-1 (1971),27. (454) Underwood, 1F, ibid. 2-4 (1671). 359. Nat. Symp. Fract. Mech., (1971).

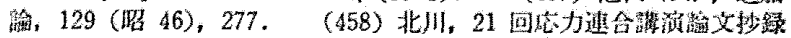

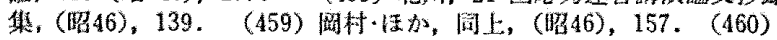
Dunegan, 濨放, Engng. Fract. Mech., 2-4 (1971), 387. (461) Sih,G.C., Tech. Rep. Lehigh Univ., 1(1969). (462) Sommer, Wh, Engng. Fract. Mech. 2-3 (1971), 235. (463) Dvorak, Int. J. Fract. Mech., 7-3 (1971), 251. (464) Kawaguchi, Y., Proc, 1st Int. Conf. Mech. Beh.

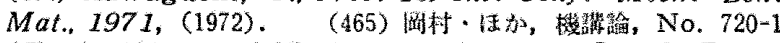
(炤 47), 195. (466) Achenbach, +12 d, Int. J. Fract. Mech., 7-1(1971), 77. (467) Ishida, M., ibid, 7-3 (1971) 301. (468) Nunomura, S.・はs, Proc. Ist Int. Conf. Mech. Beh. Mat., 1971, (1972). (469) Kitajima, K ibid. (1972), (470) Fearnehough, - 潘加, Proc. Conf. Appl. Fract. Mech. Press. Vess. Tech., (1971).

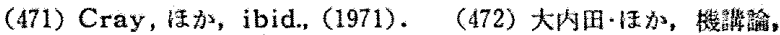
No. 710-9 (昭 46), 37. (473) Ando, S., Proc. 1st Int. Conf. Mech. Beh. Mat., 1971, (1972). (474) Kitagawa,

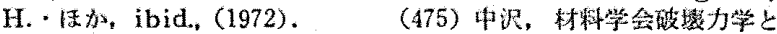

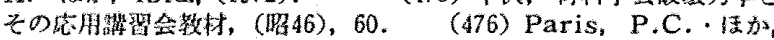
5 th Nat. Symp. Fract. Mech., (1971), (477) Bussi,

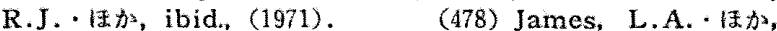
Metal Trans., 2-2 (1971), 491. (479) James, L.A., Proc. 1st Int. Conf. Mech. Beh. Mat., 1971 (1972),

James, L.A., 5 th Nat. Symp. Fract. Mech., (1971).

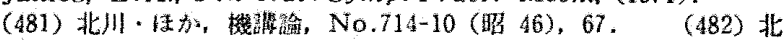

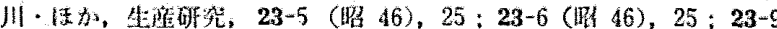

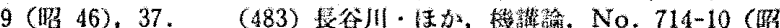
46), 73. (484) Pook, L.P., 5 th Nat. Symp. Fract. Mech., (1971). (485) Miller, ASM, 61 (1968), 442.

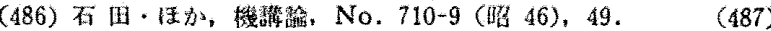
Kishimoto, H. $\mid$ खs, Proc. Ist Int. Conf. Mech. Beh.

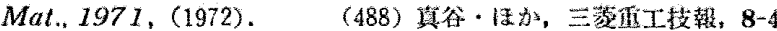
(眼 46), 1. (489) Matsumoto, T.・ほ\%, Proc. 1st Int Conf. Mech.Beh. Mat. 1971, (1972). (490) Miyamoto, H. . l

(491) Elinck.·侜, Int. J. Fract. Mech., 7-3 (1971), 277.

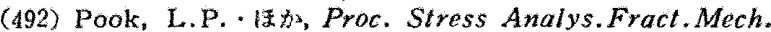
Ductile \& Brittle Mat., (1971). (493) Suzuki, - lato Proc. 1st Int. Conf. Mech. Beh. Mat., 1971. (1972), (494) Corn, Engng.Fract. Mech. 3-1 (1971), 45. Heiser, FA. - ほ Andrews, Proc. Roy. Soc. Lond., A, 325-1560 (1971), 57. (497) Gurney, T.R. 恬加, ibid., A, 325-1561 (1971), 207. (498) Clark, J, Mater. Sci., 6-1 (1971), 134. (499) Merkle, J.G., ASME, D, 93 2 (1971), 265 . (500) Mager T.R., ibid,D, 93-2 (1971), 259 .

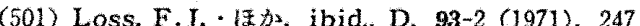
(502)

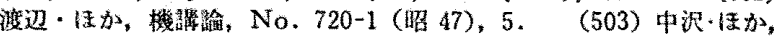

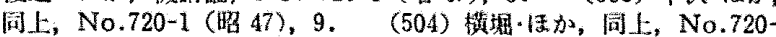

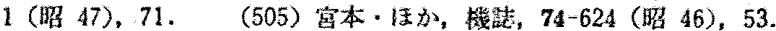
(506) Dowse, 1 小, Metal. Trans, 2-2(1971), 599. (507) Hettche, L.R., ibid. 2-7(1971), 1905. (508) Mueller, Int. J. Fract., Mech., 7-2(1971),129. (509) Smith, H.R., ibid.

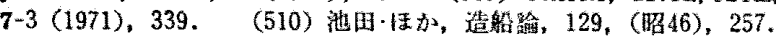

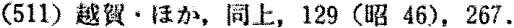
M.K., ASME, D, 93-4 (1971), 643. (512) Kassir la tongng Fract . Mech $2-4$ 
(2, Engng.Fract.Mech.2-3(1971),235. (515) Schniewind,

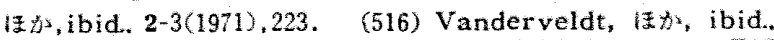

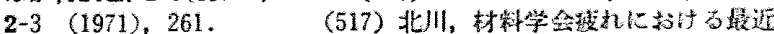

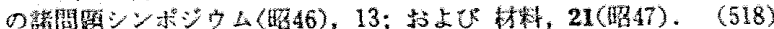

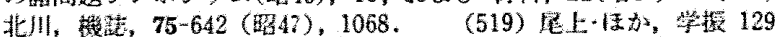

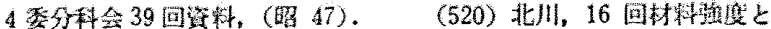

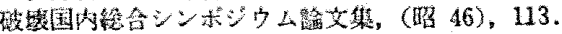

(521) Kitagawa, H., Proc.Int. Conf. Corr. Fat., 1971,

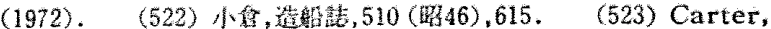
G.O.T. Engng. Fract. Mech.. 341 (1971), 1. (52A) Barsom, J.M., ibid. 3-1(1971), 15. (525) Speidel, M.O.・ 1, Proc. Int. Conf. Corr. Fat., 1971, (1972). (526)

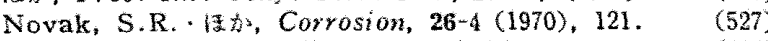
Carter, C.S., Metal. Trans., 2-6 (1971), 1621. Steigerwald, E.A., ibid., 2-2 (1971), 606. (529) Sandoz, G.. ibid., 2-4 (1971), 1055 . (530) William, Is, ibid., 2-12(1971), 3385

(531) Nelson, H.G.·仿, ibid, 2-4 (1971), 953. (532) Beachem, C.O., ibid., 3-2 (1972), 437 . (533) Nelson, 1s, ibid., 3-2 (1972), 469. (534) Carter, C.S., ibid.

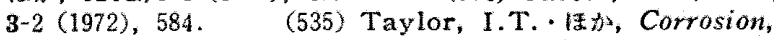
26-4 (1970), 121. (536) Steele, L.E., NRL Report, 7176

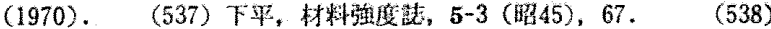

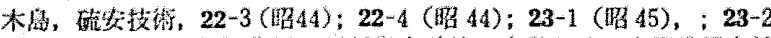

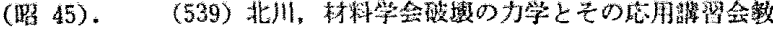

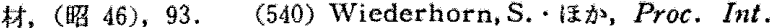
Conf. Corr. Fat., 1971, (1972).

(541) Dozier. * 传, ibid., (1972)

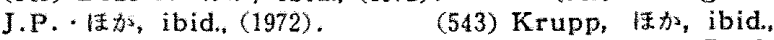
(1972). (544) Kondo, T. . 1 2 , Proc.1st Int. Conf. Mech.Beh.Mat., 1971, (1972). (545) Gallagher, J.P . (1), ibid., (1972). (546) Meyn, D.A., Metal. Trans. 2-3(1971), 853. (547) Crooker, T.W.-15, ASTM-STP 462 (1970). (548) Hartman, A.・侜, Engng. Fract. Mech, 1-4 (1970),615. (549) Wei, R.P., ibid, 1-4(1970), 633. (550) Spitzig, W.A. * 12s, ibid, 1-4 (1970), 719

(551) Pittinato, Metal. Trans., 3-1 (1972), 235. Lake, झ力s, Proc. Int. Conf. Corr. Fat., 1971, (1972). (553) Marshall, 隹放, ibid., (1972). (554) Ritter, M.A. - ⿷s, Metal. Trans., 2-11 (1971), 3229. (555) Tomkins, B., Proc. Int. Conf. Corr. Fat., 1971, (1972). (556) McClintock, F.A., ibid. (1972). (557) Nelson, H.G. . 保, ibid., (1972). (558) Duqutte, $\$$ s, Metal. Trans, 2-5 (1971), 1325. (559) Daniels, ibid., 2-7(1971),

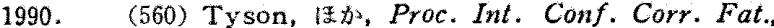
1971, (1972).

(561) Kramer, 传, ibid, (1972)

(562) McEvily,

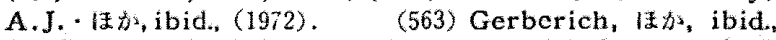
(1972). (564) Barsom, J.M., ibid., (1972). (565) Gallagher,J.P.*1zts, NRL Report, 7064 (1970). (566) Barsom, J.M., Int. J. Fract. Mech., 7-2 (1971), 163. (567) Sih, G.C., ibid, 7-1(1971), 39. (568) Chou, 施, ibid. 7-3 (1971), 331. (569) Hein, 偻, ibid. 7-3 (1972), 317. (570) Gruse, ibid, 7-1 (1971), 1 .

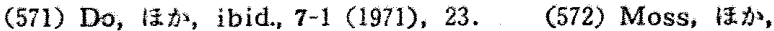
ibid. 7-1 (1971), 89 . (573) Anderson, G.P. I 1 \$, ibid. 7-1(1971), 63. (574) Bogy, D.B., ASME, E, 38-2 (1971), 377. (575) Theocaris, Proc. 7 th All-Union Conf. Photoelasticity, USSR 1971, 2 (1972), 221. (576) Erdogan, F. . If N NASA TR, 71-1 (1971). (577) 山本.

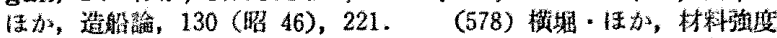

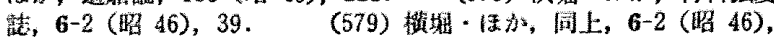

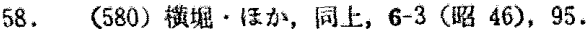

(581) 淡路・淁吕, 同上, 6-3(昭 46), 100 (582) Gallagher, J.P. Engng. Fract. Mech., 3-1 (1971), 27. (583) Shah, R.C.・好, ibid, 3-1 (1971), $71 . \quad$ (584) Kassir

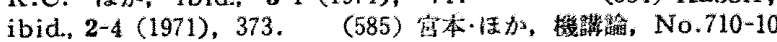
(昭 46)，17. (586) 酷谷, 同上, No, 710-10 (昭 46), 21 。

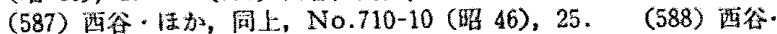

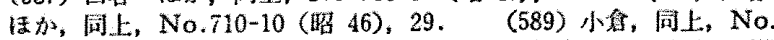

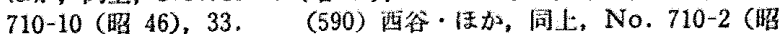
46), 159 .

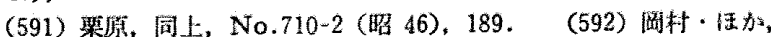
闹上, No.710-7 (昭 46)，49. (593) 畔村・传加, 同上, No.

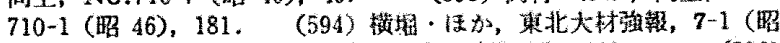
46), 25. (595) 四, 俦料, 20-214 (昭 46), 819. (596) Stanzl, S. Ift. Archiv. Eisenhüttenwes., 42-6 (1971), 411 .

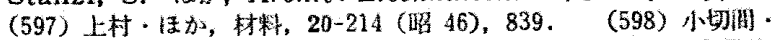

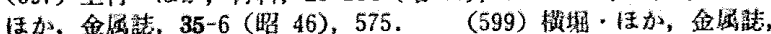
35-1 (昭 46)，70. (600) Richards, C.E., Acta Metallurg.
$19-7(1971), 583$

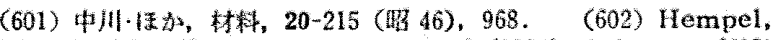
M. Archiv Eisenhuttenwes, $42-10$ (1971), 749. Park, B.K. - las, Z. Metallkde.,62-10 (1971), 721 .

(604) Hoover, W.R.*19t, Motal. Trans., 2-5 (1971), 1289.

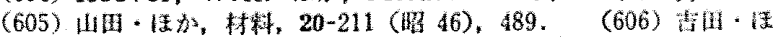

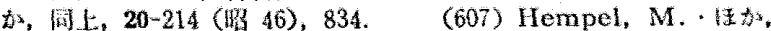
Archiv Eisenhuttenwes.42-1 (1971), 31. (608) Schwalbe, K.H., Z. Metallkde. 62-6 (1971), 472. (609) Liu. H.W. Int. J. Fract. Mech, 7-3 (1971), 269 (610) Tien; J.K. (1), Metal, Trans., 2-6 (1971), 1933.

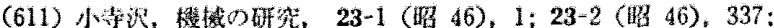

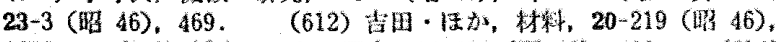

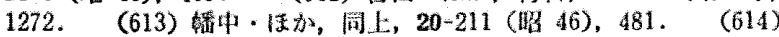

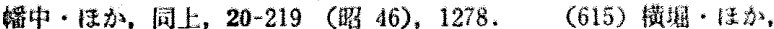

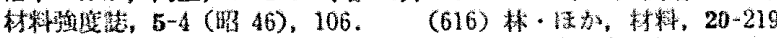
(昭 46), 1244. (617) Dönch, J*, MB, Z.Metallkde. 62 11 (1971), 780. (618) Ishii, H. $\cdot 13$, Metal. Trans. 2-12 (1971), 3441. (619) Swearengen, J.C. . (1), Acta Metallurg., 19-6 (1971), 543. (620) Schwalbe, K.H., Z. Metallkde., 62-1 (1971), 59.

(621) Flewitt, P.E.J. - Bn, Int. J. Fract, Mech.; 7-1

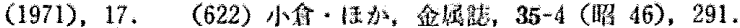

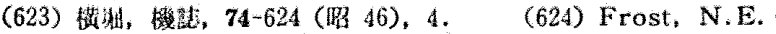
E.h, Engng. Fract. Mech., 3-2(1971), 109 (625) Barson, J.M., ASME, B, 93-4 (1971), 1190 . (626) Wunk, M.P.,

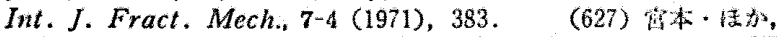

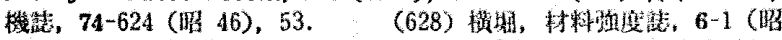
46), 18. (629) Clark, W.G., Exp. Mech., 11-9 (1971), 421 (630) Kochendörfer, A., Z. Metallkde., 62-4 (1971), 255. (631) Finniston, H.M., PIME, 185-33 (1970 71), 435.

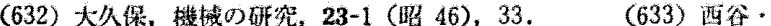
性如, 機籍, 37-300 (昭 46), 1492. (634) Hempel, M. Archiv Eisenhütenwes, 42-11 (1971), 807 . (635) 卉杢.

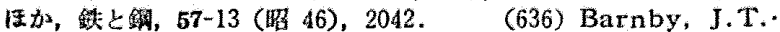

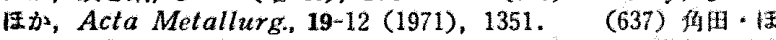

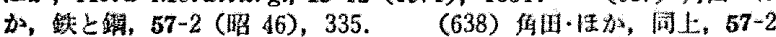

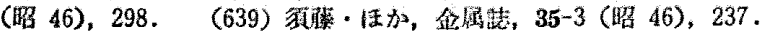

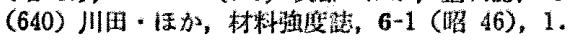

(641) Thompson, A.W.+13. Acta Metallurg., 19-7(1971), 597. (642) Hempel, M. - 加. Archiv Eisenhuttenwes. 42-11 (1971), 785. (643) Lin, T.H. If, J. Mech. Phys. Solids, 19-1 (1971), 31. (644) Bhambri, A.K. - ほzx, Metal. Trans., 2-7 (1971), 1869. (645) 酒谷・活办, 機噛, 74-632 (昭 46), 1069. (646) Heiser, F.A.・传为, ASME, D, 93-2 (1971), 211. (647) Clark, W.G., J. Mater., 6-1 (1971), 134. (648) Hahn, G.T. . If, Exp. Mech., 11-6

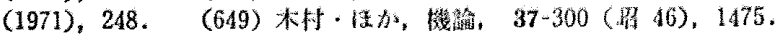
(650) Tomkins, B., Phil. Mag., 23-183 (1971), 687.

(651) LeMay, 1., J. Mater., 6-2(1971), 436. (652) 4.11.

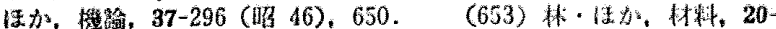

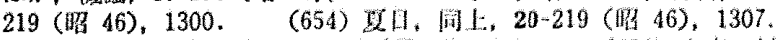

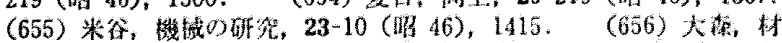
4, 20-216 (복 46), 1024。 (657) Ostermann, F., Metal Trans., 2-10 (1971), $2897 . \quad$ (658) Hempel, M., Archiv.

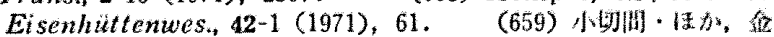

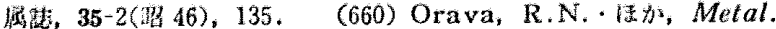
Trans., 2-6 (1971), 1675

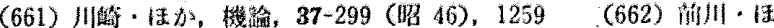
is, 网上，37-300 (昭 46)，1483 prïfung, 13-6 (1971), 187 .

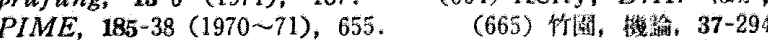
(663) Buch, A., Material (昭 46)，221. (666) Schneider, R.W. - I

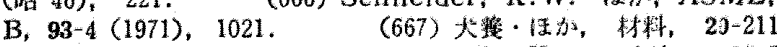
(昭 46), 458, (668) Paysan, B., Konstruktion, 23-5 (1971), 182. (669) Wellinger, K., VDI.Z, 113-8 (1971)

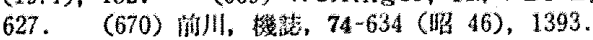

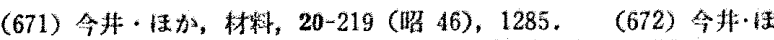

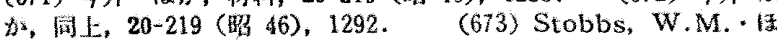
tw, Phil. Mag, 23-185 (1971), $1169 . \quad$ (674) Crooker. T.W., ASME, B, 93-4 (1971), 893. (675) Hall, L.R.

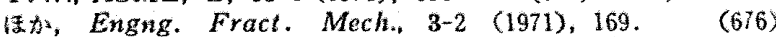
Mulcahy, T.M., ASME, E, 38-4(1971), 869. (677) Backhaus, G., Z,AMM, 51-6 (1971), 471. (678) Thang, B.Q.・12, J. Mater, 6-3 (1971), 719. (679) Coffin, L.F., ibid.,6-2

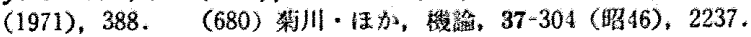
(681) Feltner, C.E. - 13, ASME, D, 93-3 (1971), 444.

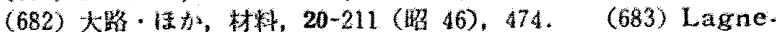
borg, R. * w, Metal. Trans., 2-7 (1971), 1821. (684) Campbell, R.D., ASME, B, 93-4 (1971), 887. 
Shahinian, P. 传数, ASME, B, 93-4(1971), 976.(686) James, L.A.・1 D, Metal. Trans., 2-2 (1971), 491. (687) McHenry, H.I., J. Mater., 6-4,1971), 862. (688) Jeglic, F.. Ifd, Exp. Mech., 11-2 (1971), 82 . (689) Organ, F.E. Metal. Trans., 2-4 (1971), 943. (690) Thiruvengadam, A. はמ, Exp. Mech, 11-7 (1971), 315.

(691) Jellinghaus, W. 汪), Archiv Eisenhüttenwes., 4211 (1971), 843. (692) Driver, J.H. - E加, J. Iron \& Steel

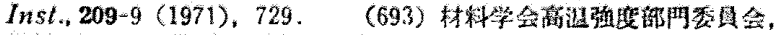
林数, 20-210(昭46), 431. (694) Ferro, A..1273, Phlí.Mag.

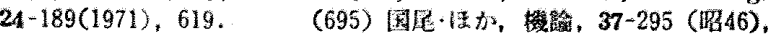
425. (696) Coffin, L.F., Metal. Trans, 2-11 (1971), 3105.

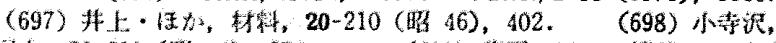

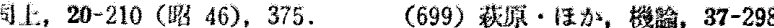
(昭 46), 1059, (700) Hempel, M.・活加, Archiv Eisen. hüttenwes., 12-1 (1971), 19.

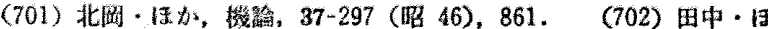

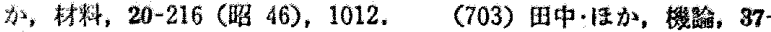

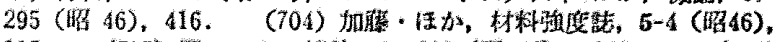

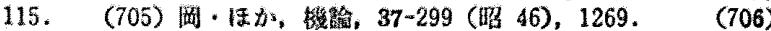
河本・注为，闰上，37-296 (昭 46)，658，(707) Hörnig, R. 住走, Materialprufung, 13-2 (1971), 53. (708) Griese, F.W., Stahl u. Eisen, 91-8 (1971), 439. (709) 中沢·はか,

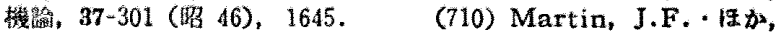
Mater. Res. Staud., 11-2 (1971), 23.

(711) Haibach, E., VDI.Z, 113-5 (1971), 397.

Korbacher, G.K Exp. Mech 11-12 (1971), 510 .

(712) (713) 中決, 譏綡, 74-633 (昭 46), 1264 . (714) Dengel, D. Materialprüfung, 13-5 (1971), $145 . \quad$ (715) Maenning W.W.. ibid., 13-1 (1971), 6. (716) 中川, 機城の研究, 23-3

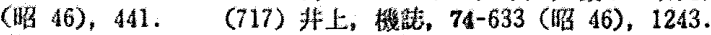
(718) Mitsche, R.·将, Z. Metallkde., 62-12 (1971), 363.

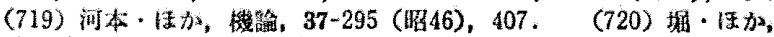

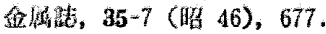

(721) Greenfield, I.G., Acta Metallurg, 19-8 (1971), 857. (722) Duquette, D.J. - 1 Is $^{2}$ Metal. Trans., 2-5 (1971), 1325. (723) Gallagher, J.P.,J. Mater., 6-4 (1971), 941.

Barson, J.M., Int. J. Fract. Mech, 7-2 (1971), 163.

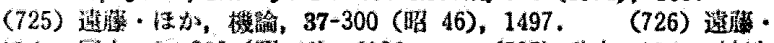

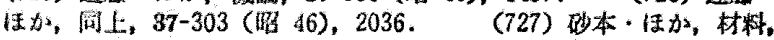

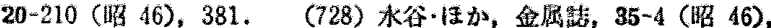

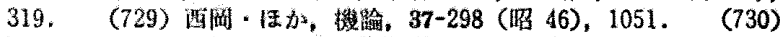
Waterhause, R.B. 俈亦, PIME, 185-46 (1970 71), 691 .

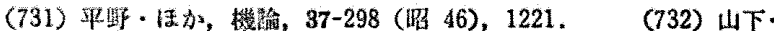

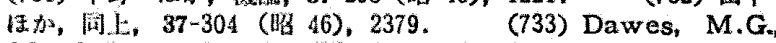
Metal Const. \& Brit. Weld, J., 3-2 (1971), 61. (734) Ferrill, D. A., Weld. J., 50-5(1971), 206-s. (735) Dowse, K.R.・㳗か, Metal. Trans., 2-2 (1971), $599 . \quad$ (736) Weiss,

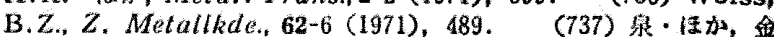

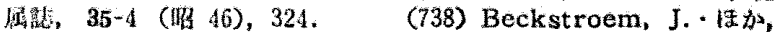
Konstruktion, 23-2 (1971), 49. (739) Jack, A.R. 汪加, Metal Const. \& Brit. Weld. J., 3-11 (1971), 416. (740)

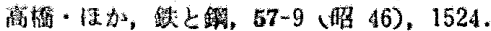

(741) Baren, M.R. •ほか, Weld. J., 50-5 (1971), 207-s. (742) Gregory, E.N., ibid., 50-10 (1971), 445-s. (743)

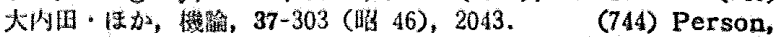
N.L., Weld. J., 50-2 (1971), 77-s. (745) Schulze, G. Konstruktion, 23-8 (1971), 307. (746) Chadwick, M.D. Metal Const. \& Brit. Weld. J., 3-10 (1971), 374. (747) Geide, K.,Z. Metallkde.,62-8 (1971), 197. (748) White, D.J.・湆加, PIME，185-28(1970 71), 339 . (749) 益本, 金

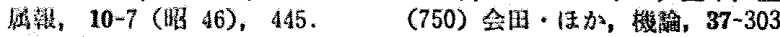
(昭 46)，2222.

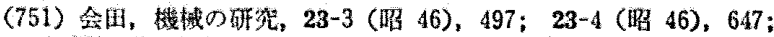
23-5 (昭 46), 760；23-6 (昭 46)，905; 23-7 (昭 46), 1019; 23-8 (炤 46), 1151；23-10 (暽 46)，1409; 23-11 (昭 46), 1535. (752) Weber, H., Konstruktion, 23-10 (1971), 401. (753) 脽谷・ほか, 材料, 20-214 (昭 46), 844. (754) Muhn, K.H. Konstruktion, 23-2(1971), 56. (755) White, D.J., PIME,

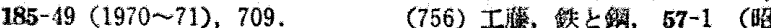
46), 47. (757) 路木・添方, 機踰, 37-299 (昭 46)，1280. (758) 路本・㴗办, 材料, 20-216 (昭 46), 1050 . (759) Elinck, J.P.・恬名, Int. J. Fract. Mech., 7-3 (1971), $277 . \quad$ (760) Mukherjee, B. - Es, Exp. Mech., 11-10 (1971), 433. (761) 枚城, 籿料, 20-211 (昭 46)，453. (762) Bunsell, A.R ほ为, J. Mater. Sci., 6-10 (1971), 1303. (763) 宦入・ほ加,

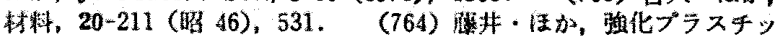
クス, 17-10 (炤 46)，438. (765) Pringle, O.A.・伍,

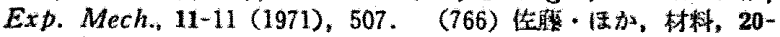

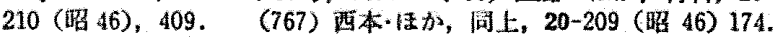
(768) PC 榴造研究委首会, 材料, 20-218 (昭 46)，1226. (769)

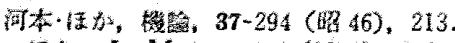
-は\$, J. Mater., 6-4 (1971), 842.

(771) 大石，封料，20-211 (昭 46)，462.

(770) Topper, T.H D. 2 , Mater. Res. \& Stand., 11-2 (1971), $19 . \quad$ (773)

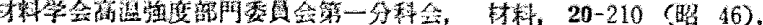
439. (774) Abst. ICM, $1 \sim 3$ (1971). (775) Prep.Ext. Sem. on High Temp. Str. Metals, (1971), 枋楼学全. (776) 䤿, 57-4, 11 (昭 46). (777) Proc. Int. Conft. Sci. \& Tech. Iron \& Steel, JISI, 11-2, Sec. 6 (1971) (778) Badiyan, E.E.・は新, J. Mater. Sck, 6-12 (1971), 1479. (779) Nakada, Y. . Metal. Trans.. 2-2(1971), 441. (780) Yamazaki, M., JISI, 11-2 (1971), 1200.

(781) Shinoda, T.・活, ibid. (1971), 1224. (782) 耳野.

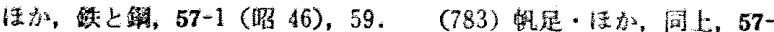
2 (昭 46), 355. (784) 田中・1加, 间上, 57-3 (昭 46), 547 .

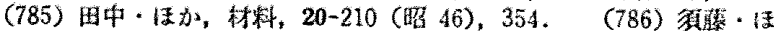

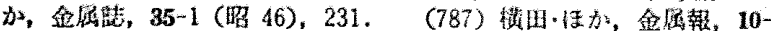

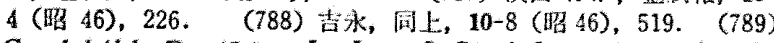
Goodchild, D.・淁, J. Iron \& Steel Inst, 209-4 (1971), 283. (790) Driver, J.H. + 传名, ibid, 209-9 (1971), 729. (791) Goldschmit, H.J. · 汪功, ibid., 209-11 (1971), 900, 910. (792) Cox, T.B.・ほか, J. Materials, 6-3 (1971), 738 . (793) Hillert, M. • \& (794) Adamson, J.P.・ほか, Acta Metallurg., 19-10 (1971), 1015. (795) Clayton, W.E.・传加, Metal. Trans., 2-2

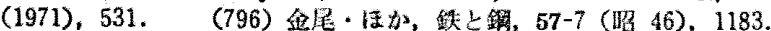
(797) Greenbank, J.C. -1 (1971), 819. (798) Tanaka, M.・仿, JISI, 11-2 (1971), 1196. (799) Geiger, T.. ibid., 11-2 (1971), 1221. (800) Hopkins, B.E.•ほか, J.Iron.\& Stecl Inst., 209-9(1971), 745.

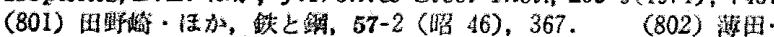

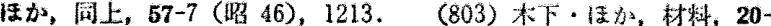
210 (昭 46), 347. (804) Murphy, M.C.・洗, J. Iron. \& Steel Inst., 209-7 (1971), 546. (805) Reynolds, G.H.' ⿷か, Metal. Trans., 2-11 (1971), $3027 . \quad$ (806) Wilson, D.J.・ほか, J. Materials, 6-4 (1971), 981. (807) 茼㗚・ほ

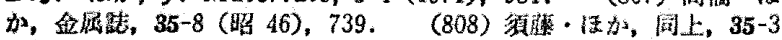

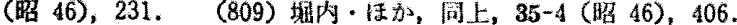

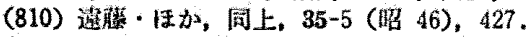
(811) Oikawa, H.・涂加, JISI, 11-2 (1971), 1311. (812) Osipov, K.A., Phil. Mag., 23-181 (1971), 167. (813) Orlova, A.・ほ加, ibid., 23-182(1971),303. (814) Pahutová, M.・㴽, ibid., 23-183 (1971), 509 . (815) Gibbs, G.B., ibid, 23-184 (1971), 771. (816) Gittus, J.H., ibid.23-186 (1971), 1281., 24-192 (1971), 1423. (817) Nix, W.D. 情多, bid., 23-186 (1971), 1339. (818) Coghlan, W.A.·情为, ibid., 28-186(1971), 1515, (819) Brown, D. 12 w, ibid, 24-187(1971), 213. (820) Moon, D.M. 活, ibid., 24-191(1971), 1087.

(821) Singhal, L.K., Scripta Metal.,5-1 (1971), 9. (822) Pahutoaá, M. 1 I W.R., ibid., 5-5 (1971), 445. (824) Beshers, D.N., ibid. 5-6 (1971), 469. (825) Gifkins, R.C., ibid., 5-7 (1971). 569. (826) Burton, B., ibid., 5-8 (1971), 669. (827) likubo, T.・1

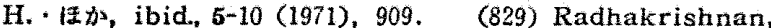
V.M., ibid., 5-12 (1971), 1073 . (830) Ahlquist, C.N. E⿰力, Acta Metallurg., 19-4 (1971), 373.

(831) Clauer, A.H. ・归, J. Mater. Sci, 6-11 (1971), 1379. (832) Latanision, R.M. ‘ 505. (833) Leverant, G.R.・传放, ibid., 2-3 (1971), 907. (834) Rainey, P.E.・は加, ibid., 2-11 (1971), 3238. (835)

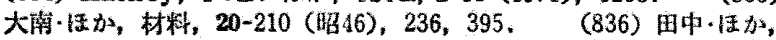

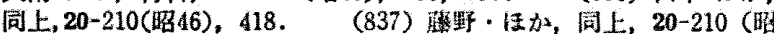

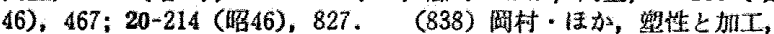
12-123 (昭 46), 292：12-126 (昭 46)，499；12-127 (昭 46), 575 . (839) Tanaka, K.・涂, Proc. 14th Japan Congr. Mater. Res., (1971), 57. (840) Sakui, S. - ほか, JISI, 11-2 (1971), 988, 991 .

(841) Nemoto, M. - 隹办, ibid., 11-2 (1971), 1010

(842) Owen, W.S., ibid, 11-2 (1971), 1301. (843) Takeyama, T. ibid., 11-2 (1971), $1307 . \quad$ (844) Liu, C.T.・加, J. Iron \& Steel Inst., 209-2 (1971), $142 . \quad$ (845) Farrell, K. ほか, ibid., 209-11 (1971), 915. (846) Lindholm, U.S.・ほ \$, J. Meterials, 6-1 (1971), 119. (847) Fotedar, H.L.. ほか, Phil. Mag., 23-184 (1971), 859., (848) Sawbridge, P.T.・ほか, ibid., 24-187 (1971), 185. C.N., Scripta Metal., 5-3(1971), 185. R.・思, ibid., 5-10 (1971), 871 .

(851) Jonas, J.J.・隹加, ibid., 5-11 (1971), 935. (849) Ahlquist. (850) Gasca-Neri, , Acta Metallurg., 19-8 (1971), 815 (853) Zeyfang, R. • 任加, ibid., 19-10 (1971), 985. (854) 
Immarigeon, J.P.A.ほ办, Acta Metallurg. 19-10(1971), 1053. (855) Bergström, Y.・活, ibid., 19-11(1971), 1243. (856) Corke, N.T.・教, J. Mater. Sci., 6-1 (1971), 68. (857) Samanta, S.K., J. Mech. Phys. Solids, 19-3 (1971), 117. (858) 小持讯, 材料, 20-210 (昭 46), 375. (859) Koterazawa, R. Proc. 14th Japan Congr. Mater. Res., (1971), 73 , (860) Langneborg. R, ASME, D, 93-2 (1971), 205. (861) Martin, J.B. • ほ (862) Gittus, J.H., Phil. Mag., 23-182 (1971), 393; 24-192 (1971), 1423. (863) Blass, J.J.・ほ为, ASME, E, 38-2 (1971), 489. (864) Sidebottom, O.M., Exp. Mcch., 11-5 (1971), 202. (865) Onaran, K.・汪放, ASME, E, 38-1 (1971), 30. (866) Morgan, C.J.・称, J. Mech. Phys. Solids, 19-4 (1971), 165. (867) Lockett, F.J. · F, ibid. 19-4 (1971), 201. (868) Carroll, M.M., ASME, E, 38-4 (1971), 847. (869) Pan, Y.S., ibid., E, 38-1 (1971), 209. (870) 村上・ほ加，譏綸，37-303(略 46)，2062。

(871) Wilson, E.A., ASME, B, 93-3 (1971), 793. 大谷・活加。材科，20-214 (昭 46),864. (873) Taira, S.・住 t3, Proc. 14th Jaban Congr. Mater. Res., (1971), 158. (874) Paslay, P.R. (875) 大南将办，籿料，20-210 (略 46)，361. (876) Advances in Creep Design, (ed. Smith, A.I. · Is Sci. Pub., London. (877) Stevens, R.N., Phil. Mag. 23-182 (1971), 265 . (878) Evans, H.E., ibid., 23-185(1971), 1101. (879) Heald, P.T.・ほ名, ibid., 23-191(1971), 1215. (880) Burton, B., Scripta Metal., 5-8 (1971), 669.

(881) Lücke, K.・活, Acta Metallurg., 19-10(1971), 1087.

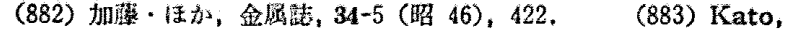
M.・加, Trans. Japan Inst. Metals, 2-2 (1971), 107. (884) Halliday, M.D.・ほ为, J. Mater. Sci., 6-10 (1971), 1254. (885) Tien, J.K.・ほか, Metal. Trans., 2-6 (1971), 1663. (886) Kirchner, H.O.K., ibid., 2-10(1971), 2861. (887)

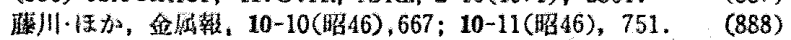
Siegfried, - W., JISI, 11-2 (1971), $1214 . \quad$ (889) Rath,

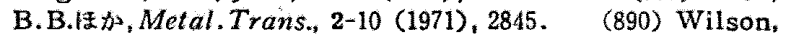
D.J., J. Materials, 6-4 (1971), 981 .

(891) Taylor, P.R.・㱙加.Iron \& Steel Inst., 209-9 (1971), 714. (892) 大路, 材料, 20-210 (昭 46), 366. (893) Harrison. C.B.・ほか, Engng. Fract. Mech., 3 (1971), 403. (894) Mchenry, H.I., J. Materials, 6-4 (1971),862. (895) Williams, J.A.・ほか, Phil. Mag., 23-185 (1971), 1155. (896) Kenyon, N.* ほ 218. (897) 抄本・婊加、材料, 20-210 (昭 46)，381。 (898) Hough, R.R. - ほ (899) Thiruvengadam, A.・ほ加, Exp. Mech., 11-7 (1971), 315. (900) Driver, J.H. •ほか, J. Iron \& Steel Inst., 209-9 (1971), 729 .

(901) Topper, T.H. ・ 加, J. Materials, 6-4 (1971), 842.

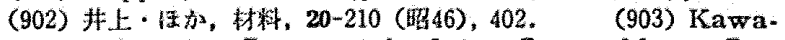
moto, M.•ほb, Proc. 14 th Japan Congr. Mater. Res., (1971), 42. (904) Conway, J.B. - ほ3, Metal. Trans., 211 (1971), 3247. (905) Thang, B.Q. - 伎汃, J. Materials, 6-3 (1971)、718. (906) 中川・这加, 材料, 20-215 (昭 46)，968. (907) Campbell, R.D., ASME, B, 93-4 (1971), 887.

(908) Lagneborg, R. ・活, Metal. Trans., 2-7 (1971), 1821. (909) Shahinian, P. • ほ ASME, B, 93-4 (1971), 976. (910) Harrison, C.B.・ほ加, Engng. Fract. Mech. 3 (1971), 403

(911) James, L.A.・ほか, Metal. Trans., 2-2 (1971), 491. (912) Jeglic, F.・胁, Exp. Mech., 11-2 (1971), 82. (913) Clark, W.G.,Jr., J. Materials, 6-1 (1971), 134 . (914)

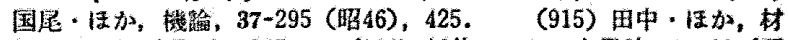

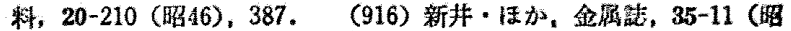

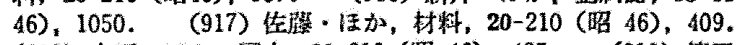

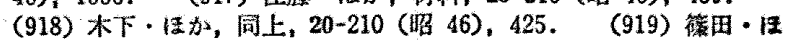

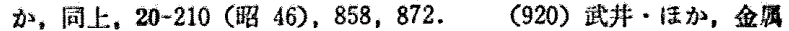
戥, 35-11 (昭 46), 1063.

(921) Taira, S.・使, Proc. 14th Japan Congr. Mater. Res., (1971), 165. (922) 機座资 (関四 15 回), (昭 46).

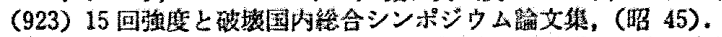

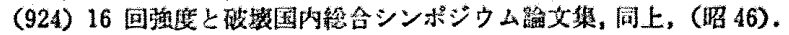

(925) Pelloux, R.M.N.. Engng. Fract. Mcch.. 1-4 (1970),

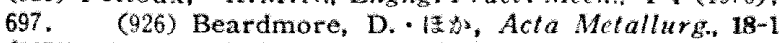
(1970), 109. (927) Richards, G.E., ibid., 19-7 (1971), 583. (928) Thompson, K.R.L. - (2), Metal. Trans., 1-4 (1970), 1047. (929) Wright, R.N.・1 \&s, ibid., 1-11 (1970), 3065. (930) Duguette, D.J. ·

(931) Fahr, D., ibid., 2-7 (1971), $1883 . \quad$ (932) Tien, J.K.* 123, ibid., 2-7 (1971), 1933. (933) Carman, C.M. $\cdot$. 屯. J. Iron \& Steel Inst., 208-5 (1970), 463 . (934) Evans, P.R.V. - ほ

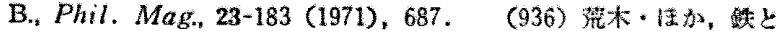

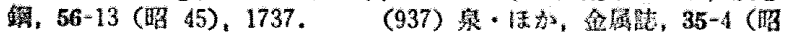
46), 324. (938) 山田・伍加, 材斡, 20-211 (昭 46)，489.

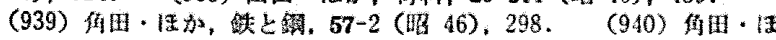
加。闹上, 57-2 (昭 46), 335 .

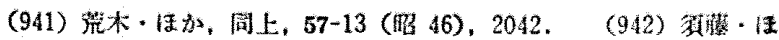

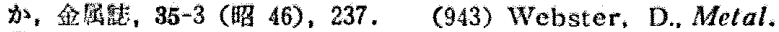
Trans., 1-10 (1970), 2919. (944) Kershaw, J., Int. $J$.

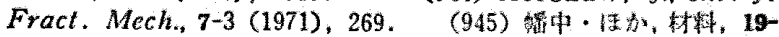
197 (昭 45), 96. (946) Walker, K., ASTM-STP 462(1970)。 1. (947) Impellezzeri, L.F., ibid., $462(1970), 40$.

(948) McMillan, J.C.・五, Engng. Fract. Mech, 2-1 (1970), 81. (949) Kokanda, S., Int. J. Fract. Mech., 6-1

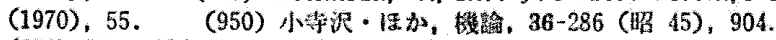
（951）解用 - 造船筑，128（昭 45)，331 (952) McMahon,

C.M.・出, Metal. Trans., 1-12 (1970), 3443. (953) Spitzig, W.A.・住D, Engng. Fract. Mech., 1-4 (1970). 719. (954) Walker, K.・13, ASTM-STP $462(1970), 234$. (955) Feeney, J.A.・㴽觔, Metal. Trans., 1-6 (1970), 1741. (956) Pittinato, G.F.・活, ibid., 1-11 (1970), 3241 . (957) Duquette, D.J.・ほか, ibid.; 2-5 (1971), 1325. (958) Ritter, D.L. - 活加, ibid., 2-11 (1971), 3229, (959) Barsom, J.M., Int. J. Fract. Mech., 7-2 (1971), 163. (960) Greenfield, I.G., Acta Metallurg., 19-8 (1971), 857.

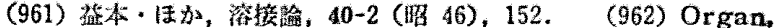

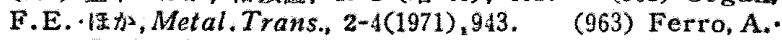
任加, Phil. Mag., 24-189 (1971),619. (964) Dowse, K.R. Metal. Trans., 2-2 (1971), 599 . (965) Schmitt-Tormas, K.G.・活, Z. Metallkde., 61 (1970), 955. (966) Schmitt-Tormas, K.G.・仿, Prakt. Metall., 7 (1970), 538. (967) Kochendörfer, A., Z. Metallkde., 62 (1971), 1. (968) Beachem, C.D. - 活3, Metal. Trans., 21 (1971), 141. (969) Williams, J.C. - \& (1971), 1913. (970) Roberts, M.J., ibid., 1-11 (1970), 3287. (971) Gerberich, W.W. • \& $\$$, ibid., 2-8 (1971), 2243.

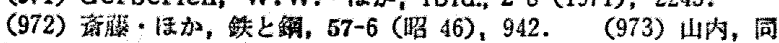
上, 57-13 (吸 46), 1897. (974) Thevenow, V.H.,J. Mater,

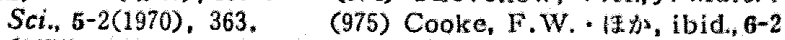
(1971), 403. (976) Wilson, F.G.・13, J. Iron \& Stcel Inst., 209 2 (1971), 126. (977) Glover, A.G. • ほ

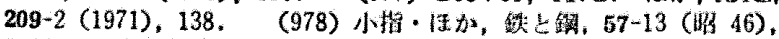
2029. (979) Rack, H.J.・18, Metal. Trans., 2-11(1971), 3011. (980) Kirman, I., ibid., 2-7 (1971), 1761.

(981) Holloway, J.R.・12, J. Iron \& Steel Inst., 209-10 (1971),813. (982) Nielsen, N.A., J.Mater.Sci, 5-4(1970) 794. (983) Thornbey, J.C. - 19, Acta Metallurg., 18-10

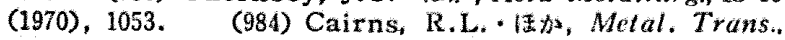
2-7 (1971), 1837. (985) Kalish, D. . ほs, ibid., 2-9(1971), 2665. (986) Jürgens, V.・はか, Schweis, u. Schneid., 23

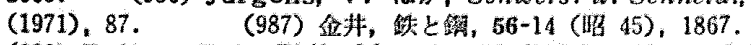
(988) Bullen, F.P., Phil. Mag., 21-172 (1970), 689. (989)

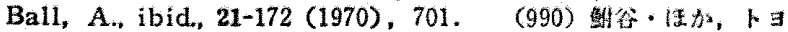
多技街，21-4 (昭 45)，245.

(991) Elinck, J.P., Int. J. Fract. Mech., 7-3 (1971), 277. (992) Marcinkowski, M.J.. 12, J. Appl. Phys., 41-11 (1970), 4753. (993) Leiris, H., Rev. Soundure Lastijdchift, 26 (1970), 183. (994) Meny, J.・任为, Metraux Corrosion Ind., 46 (1970), 340. (995) Clark, D.R.,

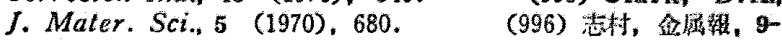

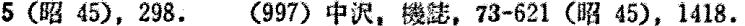
(998) 北位, 同上, 73-621 (昭 45), 1426。 (999) Henry, G., 缺と铜, 57-8 (昭 46), 1385 . 